\title{
Assessing accessibility of footpath-level walkability in old core cities of India for promoting Universal Mobility through Archi- tectural Planning Research: Case Study of Central Kolkata, In- dia
}

Gaurab Das Mahapatra ${ }^{1}$, Suguru Mori ${ }^{2}$ and Rie Nomura ${ }^{2, *}$

\author{
Laboratory of Architectural Planning, N216, Division of Architectural and Structural Design, Engineering \\ Faculty, Hokkaido University, Kita 13-Jo, Nishi 8-Chome, Kita Ku, Sapporo 060-8628, Japan; \\ suguru-m@eng.hokudai.ac.jp (S.M.); nomurarie@eng.hokudai.ac.jp (R.N.) \\ * Correspondence: gaurabdasmahapatra@gmail.com; Tel.: +81-807-025-6958
}

\begin{abstract}
In this research, the accessibility in the footpath-level walkability condition of old core cities of India has been assessed, considering Central Kolkata, India as a case. Post-2015, after the implementation of Goal Number 11 of United Nations Sustainable Development Goals (i.e. Sustainable Cities and Communities), the significance of universal mobility has globally manifolded in the walkability sector. This research has been done in theoretical, ideological, and methodological patterns using Architectural Planning Research for promoting Universal Mobility in old Indian cities. The variables (categorical) used in this research are related to pedestrian infrastructure. The categorical variables are: 1) Building Typology of Stretch, 2) Footpath Dimensions, 3) Temporary Encroachment, 4) Permanent Encroachment, 5) Bus Stop, 6) Metro Rail Entrance, 7) Railings, 8) Storm Water Drains, 9) Public Toilet, 10) Trash Bins, 11) Street Lights, 12) Flooring, 13) Manholes, 14) Kerb, 15) Pedestrian Crossing, 16) Street Furniture, 17) Safety and Security, and 18) Additional Inclusive Features like signage. This research shows that the footpath stretches in Central Kolkata, India are inadequate in terms of ideal accessibility. In addition to this, the result of this research portrays complexities in the adaptability of accessible walkability-related considerations; thereby suggesting a new accessibility audit format for old core Indian cities for achieving Universal Mobility standards in the future. The authors also propose quantitative methods to conduct future research in the same domain.
\end{abstract}

Keywords: Walkability; Central Kolkata; Accessibility, Universal Mobility; Architectural Planning Research; Accessibility Audit

\section{Introduction}

"Architectural Planning" is a generality-oriented deterministic way of relating physical and spatial factors with human life [1]. Architectural Planning Research (hereafter, APR) reflects human behavior in the built environment. The adequacy and contextuality of APR depend on three primary factors: 1) Contextual appropriateness, 2) Economic Viability, and 3) Diversification of User Group. Amongst all, the understanding of the user group is the key to a successful APR solution [2]. The role of Universal Design (hereafter, UD) is primary in this argument. UD has an essential niche in APR due to a higher degree of psychophysiological quotient than most other design paradigms. UD is defined by Ronald Mace (1985) as the design of products and environments which would be to maximum usable by all people, without the need for modifying or specializing the design [3]. However historically, amidst iconic placemaking and timeless design, architects and planners have not been able to integrate the entire user group in a holistic manner. A recent example is a case of the Constitution Bridge on the Grand Canal in Rome, where the 
Architect Santiago Calatrava was fined seventy-two thousand pounds in 2019 for not creating a citizen-friendly design [4].

Goldsmith (2000) establishes a holistic model "Universal Design Pyramid" elaborating the different user groups in a design solution, like adult able-bodied people, elderly "fit" people, independent wheelchair users, wheelchair users needing additional help, and so on. Goldsmith's model is an attempt to break away from the stereotyping of the "ideal" user group, which APR professionals often misinterpreted [5]. However, the elderly, differently-abled, and women have never been inclusively dealt with in our history [6]. Thus, the generic "successful" designs (especially Community-level projects) shall often deem misfit when evaluated multidimensionally from the perspective of UD [7].

The differently-abled people were termed as "handicapped" and "disabled", at least till the mid-twentieth century after which the terms like "differently-abled" and "specially-abled" came into effect [8]. However, in numerous documents globally available, the term "Person with Disability" is still used. Although, the distinctive nature of society towards differently-abled is reflected in human civilization from the beginning of civilization till date. In early civilization (till 4th century CE), differently-abled people were subject to begging and were used as court jesters, besides being whipped, chained, and starved to death. Belief system-wise, disability has been often linked to a curse or punishment from God; in both Aegean, Pagan, and subsequent religions [9]. During Middle Ages (5th - 13th century CE), differently-abled people were reportedly immersed and killed in boiling hot water, besides other forms of torture [10]. In Europe during the Renaissance Period (14th -17 th century CE), an estimated figure of more than eight million people (mostly women who gave birth to differently-abled children) were executed after being defamed as "witches" [11]. During the Industrial Revolution (18th - 19th century CE), although physical impairments were dealt with sympathy, mental health was not even recognized as a curable or acknowledgeable issue [12]. Being a belief system-oriented society, the condition of differently-abled people was not very different in India as well [13]. Disability was always seen as a taboo in Hindu (the major religion in India) belief systems; where a physical disability was associated with a curse/ punishment from God. Stories of Kaikeyi from Indian epic folklore Ramayana, show a lady with kyphosis (hunchback) being the primary antagonist in sending protagonist Lord Rama to a fourteen-year exile; thus, portraying a negative attribute to the differently-abled people [14].

Even in the modern history of India, the category of disabled was not even considered until the 1971 census (even after being an independent nation since 1947). However, since independence, inclusiveness related to disability existed in Article 15 of the Indian constitution [16]:

No citizen shall, on grounds only of religion, race, caste, sex, place of birth or any of them, be subject to any disability, liability, restriction or condition with regard to- (a) access to shops, public restaurants, hotels and places of public entertainment; or (b) the use of wells, tanks, bathing ghats, roads and places of public resort maintained wholly or partly out of State funds or dedicated to the use of the general public.

India needs contextual approaches in improving the livability and quality of life in its cities [17]. Along similar lines, there are numerous other guidelines published in the years following 1948. In addition to the complexities in the implementation of guidelines, old cities in India are inherently a complex platform for exercising accessibility guidelines. Mahapatra, Mori, and Nomura (2021) identifies the following reasons behind the low success of Indian disability guidelines in a spatial context- a) diversity in urban structures (like higher density in old cities compared to new planned cities), b) autonomy of state governments in land-related issues, c) lack of national-level data related to disability, and d) non-recognition of elderly and situationally disabled in the policy level considerations [18].

Thirty-three ten-million-plus cities around the world (including Delhi and Udaipur from India) participated in W.H.O.'s global "Age-friendly city" research (in 2015), involving interaction with older people, caregivers, and service providers. Since this research focuses on Universal Mobility, key factors identified from the pool of factors that W.H.O. 
suggests were used by the authors in the preparation of the questionnaire for this research. The factors are: (a) Resting space, (b) Age-friendly pavements, (c) Safe pedestrian crossings, (d) Accessible features, (e) Walkways and cycle paths, (f) Adequate Public toilets, (g) Availability of Public Transport, and (h) Age-friendly Transport stops and stations [19]. In addition to this, India being a member nation of the United Nations and taking cue the inputs from "United Nations Convention on Rights of People with Disabilities" (UNCRPD) and other similar international guidelines, had to incorporate certain elements of inclusiveness in the present Urban Development paradigm. As a result, programs like (1) "Sugamya Bharat Abhiyan" or "Accessible India Campaign" in 2015 [20], and (2) "Building Accessible, Safe \& Inclusive Indian Cities" or BASIIC in 2020 has been adopted in India to promote Universal Design [21]. Amongst all the domains of Universal Design like "Building level factors", "Information and Communication segment", "Movement and Transportation Issues" and "Site Level features", the topic of "Movement and Transportation Issues" has been dealt with major focus in this research. "Movement and Transportation Issues" is prioritized since individual building facilities alone cannot create Universally Designed cities unless those buildings are connected through a "Universally Designed" movement corridor. The aforesaid universally designed movement corridor is also referred to as Universal Mobility in technical terms.

This research attempts to propose a model of walkability assessment of historical city centers, and then verifies the model on case area. The core of Kolkata, India has been selected as a case area for this research. The next section elaborates on the historical background of the case area.

\section{Historical Development of the case area}

Indian old cities are different from many old cities around the world due to their diverse historic origin, complex transformation dynamics, and organic spatio-formal structure. The old city selected for this research is Kolkata, which is the capital of the state of West Bengal in India due to its historic origin and decaying urban core. As early as the $16^{\text {th }}$ century, Portuguese presence can be traced in and around Kolkata [22]. Armenians also had their presence in this city in the late $16^{\text {th }}$ century [23]. The early $17^{\text {th }}$ Century marked the arrival of the Dutch near Kolkata [24]. French too had made their presence near Kolkata by the late 17th century [25]. However, the major physical and social impact on the city is of the British who institutionalized the city (for their own benefit) and converted it into a city of global interest since their advent in 1690 [26]. Kolkata was also the capital of British India till 1911 [27]. After gaining independence from the torturous British Empire in 1947 [28], Kolkata remained as the centre of trade, commerce, politics, and culture; despite being plagued by various socio-political crises [29].

During the period 1947-1977, Kolkata was majorly under the rule of the Indian National Congress except for the short rule of the United Front (from 1967-1969) [30]. After this period, from 1977 till 2011 Kolkata was ruled by the Left Front (Communist Party of India-Marxist) [31]. From 2011 till date, the All India Trinamool Congress has been in power [32]. In addition to this, mostly since 1977, the ruling party in the Central Government of India has not been in consonance with the ruling party in the State Government of West Bengal (consisting of Kolkata). Thus, many beneficial national policies have not been materialised at the state level, especially since Indian Constitution (vide Article 246) mentions the control of State administration in urban development projects [33]. The old (central) part of Kolkata which has traditionally been the administrative, commercial, and educational hub has been historically associated with congestion and unhealthy living conditions [34]. The case area selected for this research in Central Kolkata has been mentioned in the oldest cartographic evidence of Kolkata prepared during British Empire. Kolkata Municipal Corporation (established in 1876) is presently responsible for the administration of the delineated case area (Refer Appendix 1).

The case area selected for this research spans over nearly $850 \mathrm{~m}$ and is aligned in North-East to South-West direction. The footpath (pedestrian area) on both the side of the 
case area is the specifically surveyed stretch. Since the inception of Kolkata in the late $17^{\text {th }}$ century, this case area has been the centre of multiple activities and associated traffic loads. The temporal change of this area (especially the "right of way" or R.O.W.) has not been proportional to an increase in population as well as associated activities. The population of Kolkata in 1911 was 896,067 in comparison to 4,496,694 as per the 2011 census. However, the average density of Kolkata (Municipal limits) in 1913 was approximately 26,500 people per square kilometre, in comparison to 24,252 (as per the 2011 census).

In similar lines, the traffic intensity map prepared by E.P. Richards in the year 1913 for Calcutta (previous name of Kolkata) Improvement Trust shows that even 100 years ago, the study area maintained a traffic intensity of 500 vehicles per hour. Subsequently, in this case area, there has been an addition of Metro Rail (underground rail/ subway) in the early 1990s; followed by mobile application-based rental cab services post-2000s. However, the case area has almost the same R.O.W. since 1913.

In relation to this, a survey by the authors in the month of September 2020 shows the number of total vehicles in peak hour as: 1) 2110 vehicles in Bowbazar Crossing, 2) 5483 vehicles in Central Avenue Crossing, and 3) 11211 vehicles in Bentinck Street Crossing. The survey format and details of the study are provided in Appendix 2. It should also be noted that due to the coronavirus pandemic, several Building Uses (including schools and private institutions) were not functioning regularly, thus considerably reducing the peak hour vehicular traffic volume recorded by the authors.

Thus, it can be concluded that, despite having the same density, the number of vehicles per hour has increased manifold; thus, putting infrastructural pressure (specifically walkability) on the sidewalks. In relation to this, research work in a similar case area, titled "Re-inventing Urban Spaces by accessing accessibility in old city core- A case of Kolkata", had concluded that the greatest problem in walkability is: 1) Lack of proper footpath- for able-bodied people, and 2) Encroachment by Vendors- for differently-abled people [35]. Also, visual observations by authors reflect that the present condition of the case area is not adequate for pedestrians and the issue of universal mobility seems like a daunting task.

The case area for this research is shown in Figure 1. 


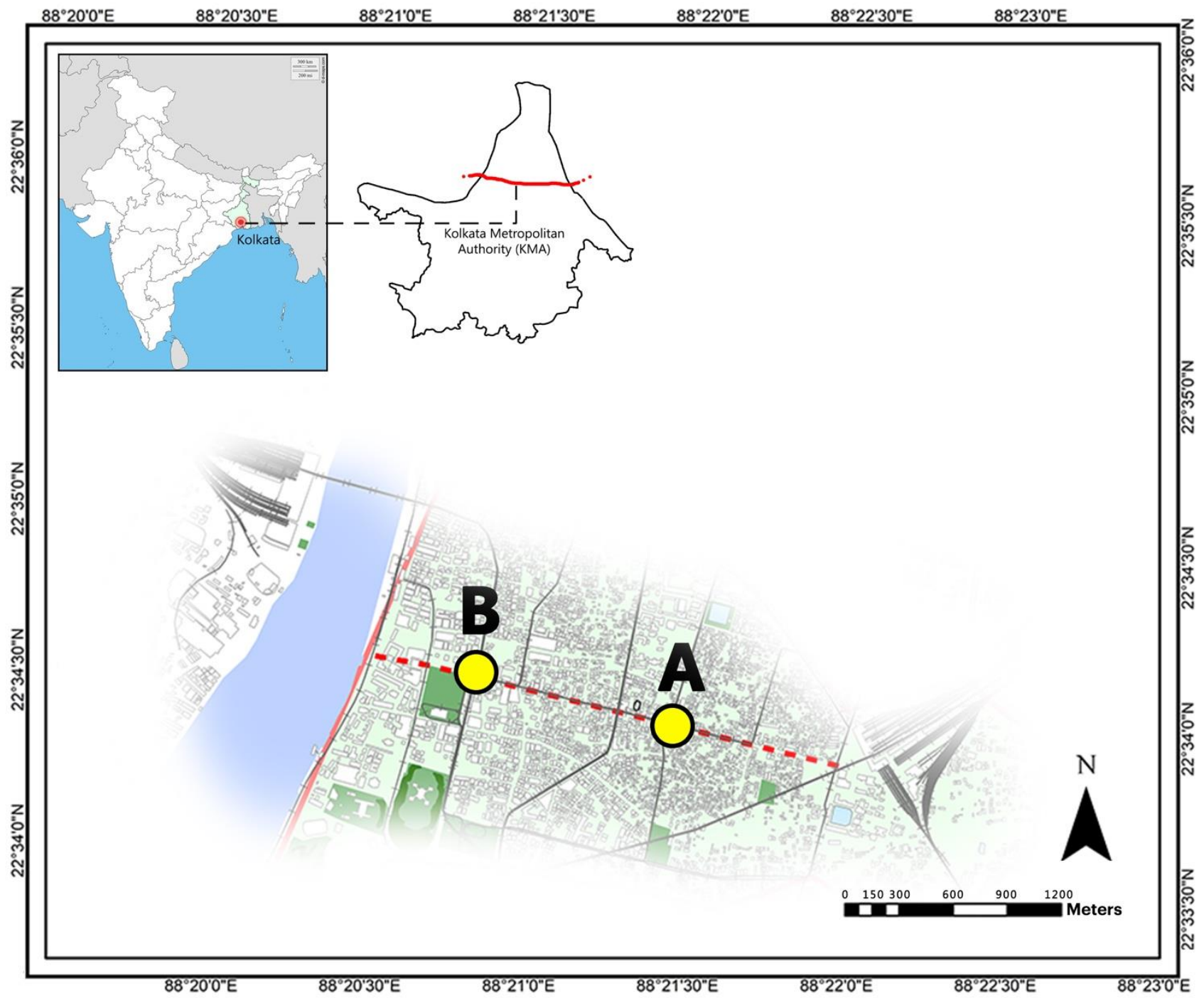

Figure 1: Study Area selected for this research. The case area is demarcated with Point A at one end and Point B on the other side. The stretch is about $850 \mathrm{~m}$ in length; oriented in Northeast - Southwest Direction; and has a walking time of about 15 minutes for able-bodied people [Source: Author].

The case area selected for this research area is further subdivided into thirty-two stretches (Explained in detail in the "Research Design" section of this paper) for strengthening the specificity of the research. The stretches are: 1) Arterial Streets, and 2) Footpath stretches between two adjacent Arterial Streets. Apart from these stretches, there are three major junctions that this stretch surpasses: Bowbazar Crossing, Central Avenue Crossing, and Bentinck Street Crossing. In all the thirty-two stretches delineated for survey in this research, the presence of residential and business building-use is observed. Buildings with mercantile Building Use are present in $71.88 \%$ (23 nos.) stretches. Subsequently, in 50\% (16 nos.) stretches, Institutional Building Use is observed. Other Building Use in the thirty-two stretches are: a) Educational - 12.50\% (4 nos.), b) Assembly $6.25 \%$ (2 nos.), and c) Industrial and Storage $-3.13 \%$ (1 no.). Hazardous Building Use is not observed in any of the stretches. The presence of different building-use in the case area is shown in Figure 2. 


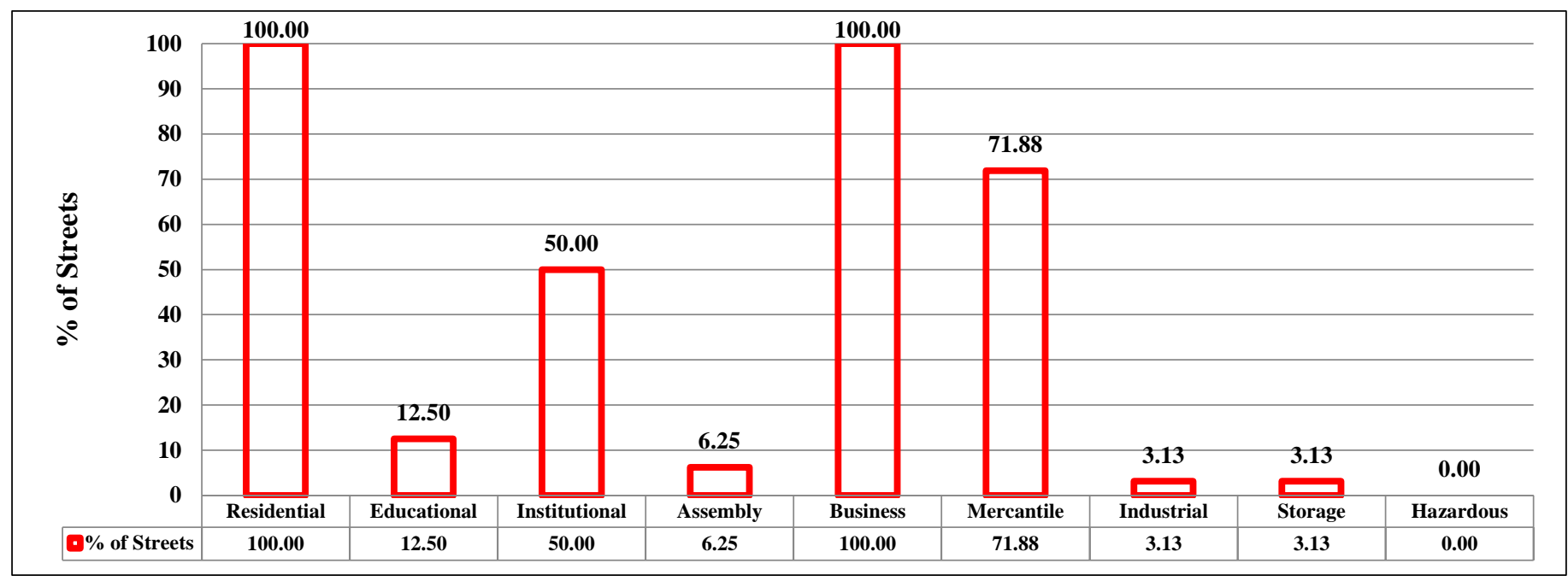

Figure 2: Presence of different building-use in the case area [Source: Author].

The next section is the Literature Study, which is a theoretical commentary on the critically prioritized aspects of mobility.

\section{Literature Study}

Gregg and Hess (2019) argue about the contextual analysis of public policies related to street-level research. The understanding of a complete (ideal) street is based on the components that the street has or might be induced; not necessarily based on a generic guideline [36]. Dividing the case area into multiple segments helps to understand the components of "time and rhythm" in public space [37]. Identifying the functionality associated with each sub-section of a relatively long stretch of the street; and classifying individual infrastructural needs based on this hierarchy is an alternative way of analysing urban mobility [38]. Martire (2017) emphasizes connecting urban history with the street genre and street pattern. The transformation of the urban fabric with respect to temporal change is an essential consideration in the architectural planning for urban mobility [39]. In similar lines, according to the theory of Natural Movement (Space Syntax), the urban spatial structure influences the movement pattern [40]. Mahdzar (2013) suggests empirical observation of pedestrian activities before mapping the surveyed stretch. Mahzdar (2013) also mentions the categorization of physical elements of analysis into: 1) Building, 2) Street, and 3) Land Use [41]. In the same way, spaces should be analysed from the viewpoint of element spaces in order to assess the universal nature of the space [42]. Southworth (2020) has established the intricate relationship between soundscape and visual environment, which is a step towards creating an environment of universal nature [43]. Geurs and Wee (2004) establish that for urban infrastructure, the four major bases of accessibility measures are: 1) Infrastructure, 2) Location, 3) Person, and 4) Utility [44]. There are numerous ways to evaluate the accessibility of urban infrastructure, including complex ones like "Non-numerical Unstructured Data Indexing Searching and Theorising" (NUD-IST 4.0) [45]. Similar accessibility measurements also include the Public Transport Accessibility Index (LUPTAI) and the Public Transit and Walking Accessibility Index (PTWAI). Similar tools include The Path Environment Audit Tool or PEAT [46] or Mesurement Quality Appraisal Instrument or MQAI [47]. The major concern in assessing accessibility is the "relative accessibility" because accessibility is a comparative component in urban infrastructure [48]. Quite close to "relative accessibility" is the concept of "perceived accessibility", which is a measure of living a satisfactory life using public transportation [49]. The composite measures of modal experience can be acquired through a cognitive understanding of a built environment. Along similar lines, wayfinding and its associated travel experience of an individual pedestrian can be ideally explained by cognitive maps [50]. In 
addition to this, urban cores having historic origin (like the case area for this research) need "Conservation Assessment" besides generic Accessibility Audit [51].

Instead of overarching national guidelines, a Local Accessibility Plan is better suited for Indian cities [52]. Owing to the Indian practice of extensive use of public transport and walkability for daily commuting, the urban structure considerably influences mobility. Thus, it is important to correlate the city-specific characteristics to urban mobility [53]. Similarly, for accessibility surveys in congested urban cores, besides considering the goals mentioned in United Nations Sustainable Development Goals (hereafter, UN-SDG) it is also essential to identify "contextual" infrastructural indicators for Urban Mobility [54]. Amongst the city-specific features, Land Use is one of the most important factors. Litman (2016) argues that high density complemented by multiple activities has a manifold impact on the rate of accessibility; and consequently, walkability can be improved if travel distances are shorter. Litman further explains the different genres of accessibility based on the type of route; for example, 1) End of roadway, 2) Centre of Roadway, 3) Loop-type Road, 4) Crossroads, and 5) Grid patterns [55]. Scenario Analysis after classification of urban crossings helps in understanding pedestrian environments [56]. Along these lines, Evans (2009) holds that a specific "design index" for assessing inclusivity in a journey environment is necessary. The macro and micro elements (and attributes) of a street can be assessed through observational audit and strategic mapping [57].

Auditing in different parts of the same region to access the situation correctly shall foster a tailor-made/ site-specific recommendation for accessibility audit [58]. In similar lines, critical study of local policies before the assessment of pedestrian accessibility and bicycle accessibility shall be beneficial for imparting urban level accessibility [59]. However, the technically apt methodology to impart urban level accessibility is to develop a framework for "level of service" based on parameters (and their respective indicators) that influence Universal Mobility. The parameters (and their respective indicators) should be evaluated through an objective scoring/ ranking/ rating system, which in turn can be determined by a pilot survey. Besides these, identification of essential/ critical parameters (and their respective indicators) whose presence ensures Universal Mobility and viceversa, is also recommended [60].

Mobility in pedestrian areas (footpath) in core cities includes parameters like 1) Traffic factors (like, car parking), 2) Geometry/ Environmental/ Footpath factors (like, pavement conditions), and 3) Pedestrian Movement factors (like, pedestrian volume) [61]. United States Department of Health and Human Services (2005) proposes a Likert-scale based walkability audit tool (under Healthier Worksite Initiative) comprised of nine parameters, like: 1) Pedestrian Facilities, 2) Pedestrian Conflicts, 3) Crosswalks, 4) Maintenance, 5) Path Size, 6) Buffer, 7) Universal Accessibility, 8) Aesthetics, and 9) Shade. This walkability audit tool also segregates the nine parameters into three segments based on their importance in walkability [62]. Story and Mueller (2004) have established certain "performance measures" for supporting Universal Design through a stakeholder participatory approach. Along similar lines, the effectiveness of these "performance measures" relies heavily on the stakeholders" perspective of inclusiveness [63]. Scott (2014) indicates the need for explicit consideration of parameters for pedestrian-focussed Universal Mobility solutions, like: 1) Footpath Gradient, 2) Tactile Surface Ground Indicators (TGSIs), 3) Gratings, 4) Kerb Ramp, 5) Signage, and 6) Public Art. Scott also identifies indicators for each parameter in the form of "key design features"; for example: the indicators for parameter "Gradient" is "cross fall less than 1:40" [64]. Wieters (2016) identifies technology (like, Online Survey) as one of the tools in research involving walking habits in the built environment [65]. Mosca and Capolango (2018) explain that post accumulation of requisite data for understanding universal mobility, the evaluation methods can be categorised into three types of user needs, 1) Potential, 2) Actual, and 3) Actual/ Potential. Mosca and Capolango (2018) further state that the combination of the three aforesaid types might render better results [66]. The walkability of existing pedestrian walkways, which is an essential component of Inclusive society, is best evaluated using a multicriteria method [67]. Along similar lines, pedestrian access and mobility plan are suited for 
ensuring Universal Mobility. This plan is a product of Architectural Planning since it involves a research-based audit-fostered pedestrian route development [68]. Through urban street-level imagery, the urban environment can be understood from a human perspective [69]. Thus, the authors of this research have considered imagery as an important tool for this research.

Smart cities can enhance walkability for all by providing: 1) navigation applications, 2) environmental data in real-time, 3) Public Transport data in real-time, and 4) enhancing communication between pedestrians and city administration. In planning terms, the old and new cities demand different guidelines; especially in India, where the "Smart City" (urbanism propelled by Information, Communication and Technology or ICT) wave is seldom focussed on identifying the historic nature of the cities. Thus, to ensure peoplefriendly approaches in traditional organically developed compact cities, it is necessary to take into consideration the origin of the spaces [70]. However, the "Smart City" guidelines include the factors of physical accessibility in outdoor movement besides other technology-based inclusive features in urban environments [71]. In India, the recognized categories of "Persons with Disabilities" changed gradually from seven (in PwD Act, 1995) to five (in 2001 Census) to eight (in 2011 Census) to twenty-one (in $2016 \mathrm{RPwD}$ Act). Hereafter, any urban development is supposed to be inclusive for the identified group as well. In spite of identifying accessibility as the major component of Smart Cities, no comprehensive contextual audit format for assessing Urban Mobility has not been considered [72]. Legislative support and Architectural planning are equally essential to ensure an Inclusive society [73]. In the Indian post-independence (in 1947) period, there have been repeated efforts to ensure an equitable social condition by including the needs of differently-abled and elderly. There have been several guidelines like - Policies, Acts, Rules, Regulations, Notifications, and Schemes, to facilitate the differently-abled people and elderly; especially in the field of Architecture, Civil Engineering, and Planning. However, these guidelines have not been able to bring about a radical change in the Universal Design paradigm of Urban India [74]. Appendix 3 shows the chronology for the development of regulatory mechanisms in India.

Apart from these, there have been several International guidelines that have directly or indirectly influenced the Indian Guidelines. Declaration on the Rights of Disabled Persons (1945), International Convention on the Elimination of All Forms of Racial Discrimination (1965), The International Covenant on Civil and Political Rights (1966), The International Covenant on Economic, Social and Cultural Rights (1966), Declaration on the Rights of Mentally Retarded Persons (1971), Convention on the Elimination of All Forms of Discrimination Against Women (1979), World Programme of Actions (1982), Convention against Torture and Other Cruel, Inhuman or Degrading Treatment or Punishment (1984), Convention on the Rights of the Child (1989), The American with Disability Act (1990), Proclamation on the Full Participation and Equality of People with Disabilities in the Asian and Pacific Region (1992), UN Standard Rules on the Equalization of Opportunities for People with Disabilities (1993), Beijing Declaration (1995), Biwako Millennium Framework towards an Inclusive, Barrier-free and Rights-based Society for Persons with Disabilities (2002), UN-CRPD (2006), Incheon Strategy (2012), United Nations Sustainable Development Goals or UN-SDG (2015), and New Urban Agenda (2017) are some notable amongst them [75].

However, the realization of these guidelines at the Urban Level (especially old cores) has not taken place in India due to complex administrative issues. Thus, there is a need to prepare a specific research methodology to understand the aspect of Universal Mobility in the city cores of Urban India.

As an exercise for ideal/ inclusive streetscape study, the authors did a rapid baseline assessment of certain footpath stretches in Sapporo, Japan (Refer Figure 3: a to f). Japan is a country with a large number of elderly ( $28 \%$ of the total population) and $4.3 \%$ differently-abled citizens, considers a Universally Designed streetscape as a prerequisite to Urban development [76]. 


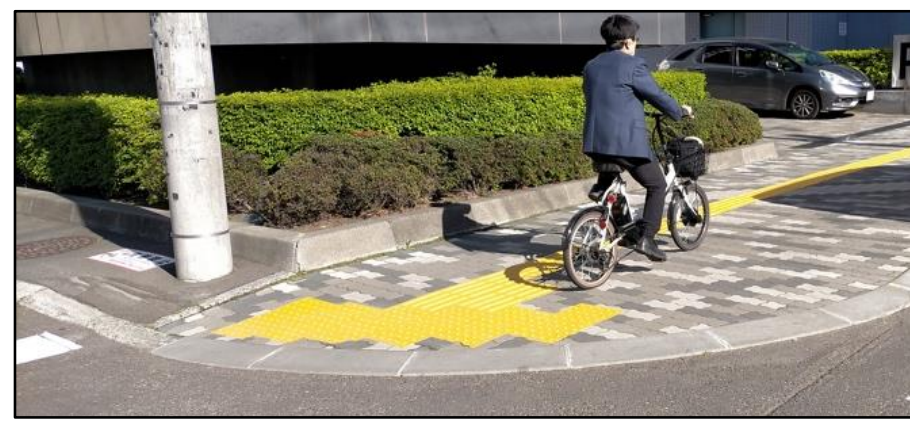

(a) Slope and Tactile Marking

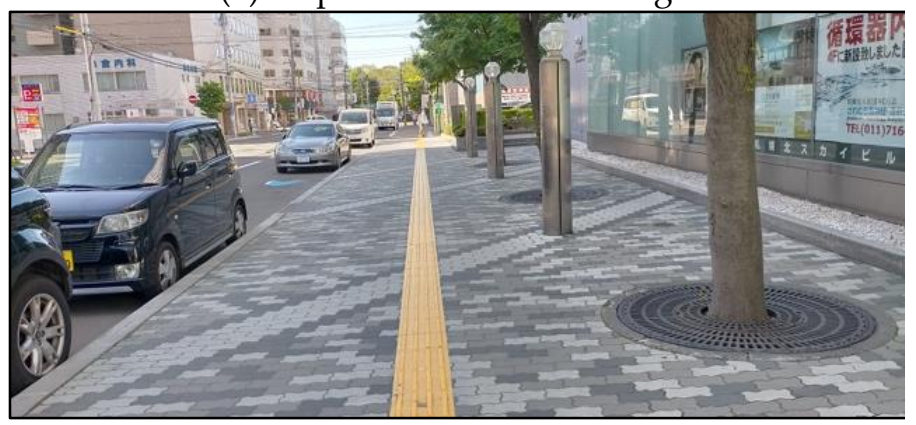

(c) Grating Change near Trees

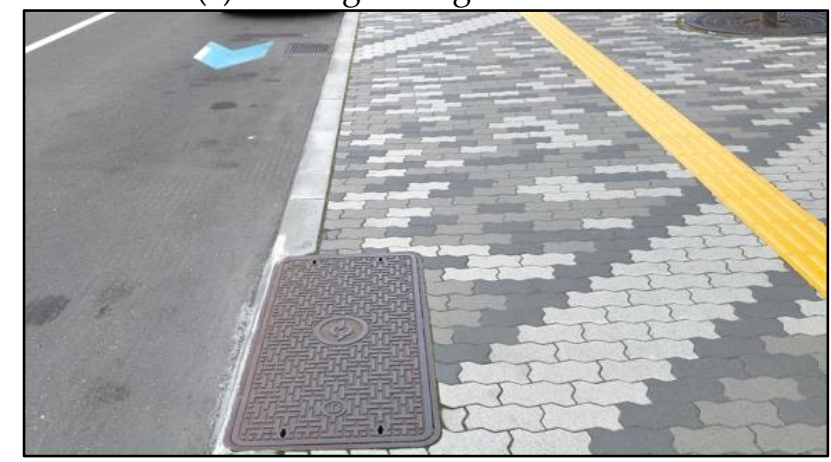

(e) Closed Manhole located on edge

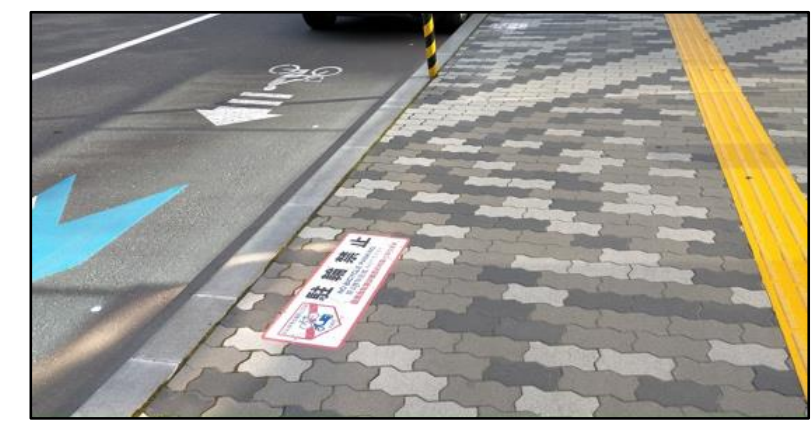

(b) Street Signage

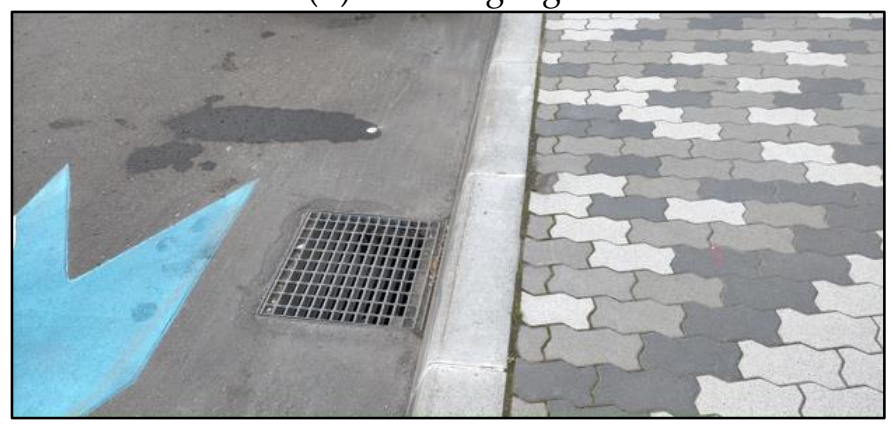

(d) Manholes away from Kerb (Kerb<150mm)

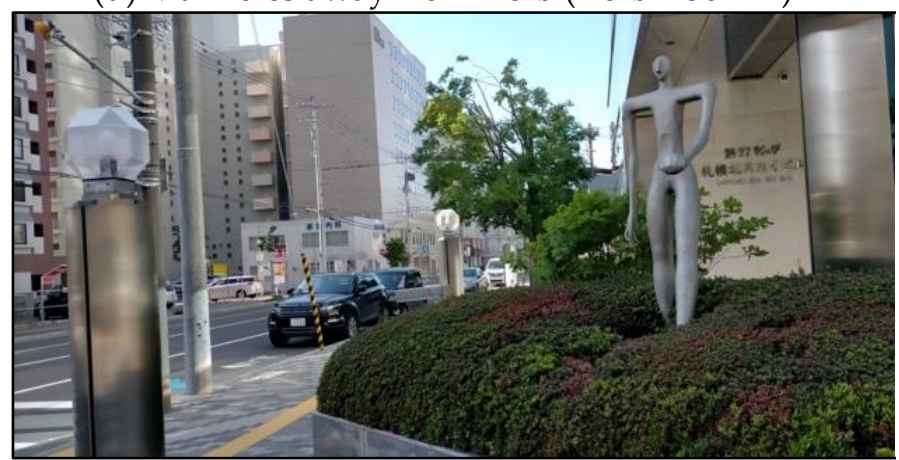

(f) Street Art

Figure 3: a-f): Location: Footpath near Hokkaido University South Gate in-between 'North 7 West 6 ' and 'North 6 West 5' [Source: Author].

Mahapatra, Mori, and Nomura (2021) in their paper "Universal Mobility in Old Core Cities of India: People's Perception" used "Critical Instance" Case Study type research for similar genre of research, suggested that there is a need for framing a new assessment framework for assessing the scope of Universal Mobility in old Indian cities. In relation to this, research of this genre requires a specific approach towards the site context, and thus cannot be conducted using generic research methods (from the familiar methods of research design). The next section elaborates on the Research Design adopted for this paper. The research design has considered the context of the study area (as discussed in the "Historical Development of the Case Area" Section), the Literature Study (as discussed in this section), and previous research by authors.

\section{Research Design}

The hypothesis considered by the authors states that the poor walkability condition is a major hindrance towards transforming the core Indian cities into Universally De-

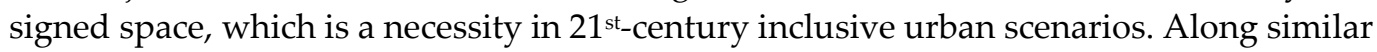
lines, the deteriorated mobility conditions pose a threat to people with functional and cognitive limitations, including elderly people. Furthermore, there is a need to frame a new assessment framework for Universal Mobility for these old Indian cities, since the usual (generic) factors of walkability have no/ negligible influence on the pedestrian 
volume in these areas. The inquiry mode for this research is "Structured". In Structured research methods, the analysis is dependent on the type of data collected.

Consequently, an "Infrastructural Conditions mapping" was conducted in the case area, which was further subdivided into thirty-two stretches. The "Infrastructural Conditions mapping" segment is composed of eighteen categorical variables. The categorical variables (considered as "Criteria" during survey and analysis hereafter) are: 1) Building Typology of Stretch, 2) Footpath Dimensions, 3) Temporary Encroachment, 4) Permanent Encroachment, 5) Bus Stop, 6) Metro Rail Entrance, 7) Railings, 8) Storm Water Drains, 9) Public Toilet, 10) Trash Bins, 11) Street Lights, 12) Flooring, 13) Manholes, 14) Kerb, 15) Pedestrian Crossing, 16) Street Furniture, 17) Safety and Security, and 18) Additional Inclusive Features. These Criteria are further subdivided into respective sub-criteria (fifty in total). These sub-criteria can be further grouped into two types of variables: Independent, and Dependent. As an example, for one of the categorical variables (criteria) "Public Toilets", the associated sub-criteria are: 1) Presence of Public Toilet, and 2) Functional Public Toilet. In this example, the "Presence of Public Toilet" is independent of any factor; however, "Functional" condition of the public toilet can be assessed if the public toilet is present at all. Thus, the sub-criterion "Presence of Public Toilet" is an independent variable, and "Functional Public Toilet" is a dependent variable.

The subsequent survey format for understanding "Infrastructural Conditions" (through primary observation) was framed based on these criteria and sub-criteria. Postsurvey, the observations were further analysed using a scoring pattern. The sub-criteria was scored based on their associated variable type (independent or dependent). The presence of a sub-criterion is scored as either " +0.50 " if the associated variable is an Independent Variable. In similar lines, a sub-criterion is scored as " +0.25 " if the associated variable is a Dependent Variable. Similarly, the absence of a sub-criteria is scored as "- 0.50 " for Independent Variables and "- 0.25 " for Dependent Variables respectively. Since each subcriterion is essential for a stretch to qualify as a Universally Designed space, the sub-criteria are given equal weightage, i.e. \pm 0.50 for the independent variable and \pm 0.25 for the dependent variable. Appendix 4 explicitly shows the Variables (Criteria and Sub-Criteria), Types of Variables (Independent/ Dependent), Scoring Logic, and the Individual Scores used in this research. For any study stretch surveyed using this framework, the consolidated highest score can be twenty (and subsequently, the lowest can be -20). It is to be noted that although all these variables are not equally important for pedestrian activity; however, negative impact of any one of them could lead to inadequate Universal Mobility standards.

Each of the thirty-two stretches in the delineated case area within Central Kolkata was surveyed based on the above methodological framework using the "Online Google Form" type Survey Format. The type of questionnaire is the "Dichotomous Close-ended" type. The Google Form is available online at https://forms.gle/EmTMDYvA34XZq4Hk9 (accessed on 23rd May 2021) and is shown in Appendix 5.

\section{Survey and Findings}

This section may be divided by subheadings. It should provide a concise and precise description of the experimental results, their interpretation, as well as the experimental conclusions that can be drawn. For mapping "Infrastructural Conditions" for this research, Field Surveys were conducted between 1st August 2020 and 2nd September 2020. The surveys were conducted with the help of some local people (students and professionals) who were acquainted with the surveyed study area. The details of local people who helped the authors are duly mentioned in the acknowledgement section. The recorded data from the study area (Central Kolkata, India) was eventually compiled and analysed in the Laboratory of Architectural Planning (Hokkaido University, Japan) between 14th December 2020 and 1st March 2021. Figure 4 indicates the locations selected for the survey using the variables considered. Table 1 shows the details of the locations and stretches illustrated in Figure 4. 


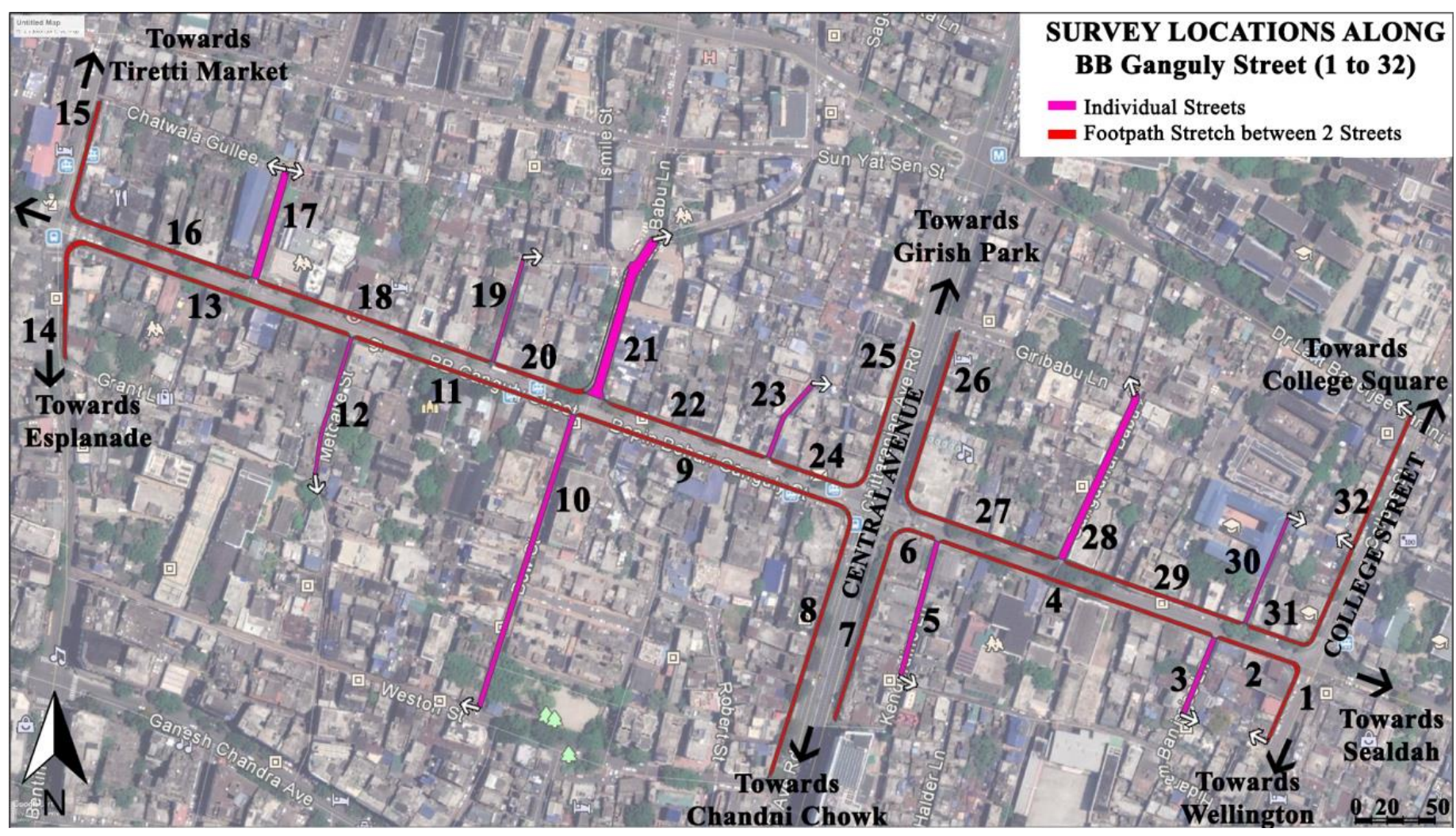

Figure 4: Survey Locations (1-32) [Source: Google Map overlayed by Author].

Table 1. Details of the case area relating to the corresponding code in Figure 4.

\begin{tabular}{|c|c|c|c|}
\hline $\begin{array}{l}\text { Correspond- } \\
\text { ing Numbers } \\
\text { in Figure } 4\end{array}$ & Stretch Details & Length (in $\mathrm{m}$ ) & Width (in m) \\
\hline 1 & Nirmal Chandra Dey Street & 51.49 & 2.10 \\
\hline 2 & Bowbazar Crossing to New Bowbazar Lane & 56.42 & 2.00 \\
\hline 3 & New Bowbazar lane & 51.68 & 5.00 \\
\hline 4 & New Bowbazar Lane to Kenderdine Lane & 184.18 & 2.00 \\
\hline 5 & Kenderdine Lane & 87.62 & 3.00 \\
\hline 6 & Kenderdine Lane to Central Avenue & 25.47 & 2.10 \\
\hline 7 & $\begin{array}{l}\text { Central Avenue (GATE 4: Yogayog Bha- } \\
\text { wan) }\end{array}$ & 126.43 & 2.10 \\
\hline 8 & Central Metro (GATE 1: Indian Airlines) & 176.77 & 2.10 \\
\hline 9 & Central Avenue to Bow Street & 185.13 & 2.00 \\
\hline 10 & Bow Street & 26.84 & 3.80 \\
\hline 11 & Bow Street to Metcalfe Street & 147.32 & 2.00 \\
\hline 12 & Metcalfe Street & 89.00 & 3.50 \\
\hline 13 & Metcalfe Street to Bentinck Street & 187.46 & 2.10 \\
\hline 14 & Bentinck Street & 72.04 & 2.10 \\
\hline 15 & Rabindra Sarani Rd. & 72.37 & 1.90 \\
\hline 16 & Rabindra Sarani Rd. to Chatawalla Gully & 121.60 & 2.10 \\
\hline 17 & Chatawalla Gully & 70.94 & 3.50 \\
\hline 18 & Chatawalla Gully to Phears Bye Lane & 157.79 & 2.00 \\
\hline 19 & Phears Bye Lane & 66.03 & 2.00 \\
\hline 20 & Phears Bye Lane to Phears Lane & 61.27 & 2.00 \\
\hline 21 & Phears Lane & 57.85 & 4.80 \\
\hline
\end{tabular}




\begin{tabular}{cccc}
\hline 22 & Phears Lane to Giri Babu lane & 109.10 & 2.10 \\
\hline 23 & Giri Babu lane & 54.62 & 2.40 \\
\hline 24 & Giri Babu lane to Central Avenue & 59.98 & 2.10 \\
\hline 25 & Central Metro (GATE 2: Lalbazar) & 110.67 & 1.90 \\
\hline 26 & Central Avenue (GATE 3: RITES) & 115.52 & 1.80 \\
\hline 27 & Central Avenue to Gangadhar Babu Lane & 102.96 & 2.10 \\
\hline 28 & Gangadhar Babu lane & 109.26 & 5.00 \\
\hline 29 & Gangadhar Babu Lane to Bibi Rozio Lane & 121.37 & 2.00 \\
\hline 30 & Bibi Rozio Lane & 72.50 & 1.80 \\
\hline 31 & Bibi Rozio Lane to Bowbazar Crossing & 42.44 & 1.90 \\
\hline 32 & College Street & 163.12 & 1.90 \\
\hline
\end{tabular}

[N.B.: The "width" refers to the predominant width that the footpath is having and is measured physically at different sections of the same footpath during the primary survey. The respective widths are measured physically on-site during the primary survey. The "length" refers to the measurement of the external kerb of the footpath that is connected to the adjacent road and is measured using satellite imagery.].

The elaborate observation and scoring of Criteria (and Sub-Criteria) with respect to each surveyed stretch is tabulated as an additional document to this paper. In relation to this, the findings are summarised hereafter.

Among the thirty-two stretches selected for the survey, 100\% of them bear the presence of buildings having 'two or more' building uses within a single building. The building use ranges from: a) Residential, b) Educational, c) Institutional, d) Assembly, e) Business, f) Mercantile, g) Industrial, h) Storage, and g) Hazardous. In addition to this, heritage structures are present in $84.4 \%$ ( 27 nos.) of the stretch.

Based on the adjacent predominant "commercial/ mixed" land-use in the surveyed stretch, the ideal width of the footpath should have been $2500 \mathrm{~mm}$. Moreover, since the pedestrian stretches are adjacent to the buildings, a "Dead Width" of $500 \mathrm{~mm}$ should be present over and above the $2500 \mathrm{~mm}$ [77]. However, among the thirty-two surveyed stretches, $78.1 \%$ ( 25 nos.) of them had a width of less than $2500 \mathrm{~mm}$. $65.6 \%$ (21 nos.) among the thirty-two surveyed stretches do not have an unobstructed width of $1800 \mathrm{~mm}$. However, there is an unobstructed clear height of $2200 \mathrm{~mm}$ in $71.9 \%$ (23 nos.) of the surveyed stretch.

Unorganized Informal Vending is observed in $46.9 \%$ (17 nos.) of the thirty-two stretches that were surveyed. However, Informal vendors/ hawkers are away from the line of pedestrian flow in $18.8 \%$ (6 nos.) of the surveyed stretches. Beggar, and/or Homeless people, and/ or Child Labour are existent in $21.9 \%$ (7 nos.) of the entire surveyed stretch.

Places of religious interest are existent in $68.8 \%$ (22 nos.) of the surveyed stretches. The eminent ones are "Saint Francis Xavier" Church, "Firingi Kali Bari" Temple, "Sri Sri Ghanteshwar Mahadev" Temple, and "Carey Baptist" Church. 78.1\% (25 nos.) of the surveyed stretch were encroached by existing establishments. In $21.9 \%$ (7 nos.) of the surveyed stretch, Communal Open Bath is present and functional.

Among the thirty-two surveyed stretches, public buses stop informally at 50\% (16 nos.) during various times of the day. However, Bus Stop is present in only $3.1 \%$ (1 no.) and that one cannot be considered functional as per design standards.

"Central Metro" is the corresponding Metro Rail/ Subway station in the surveyed stretch. The four gates of Central Metro are present in the stretch: a) Gate 1-Indian Airlines, b) Gate 2-Lalbazar, c) Gate 3-RITES, and d) Gate 4-Yogayog Bhawan. In relation to that, 25\% (8 nos.) stretches have the presence of Metro Rail Entrance alteast at one end of the stretch. However, Metro Rail entrances in working conditions are observed in 15.6\% (5 nos.) of the eight stretches. 
Railings along the surveyed stretches are existent in $40.6 \%$ (13 nos.) of the thirty-two surveyed stretches. Among the thirty-two surveyed stretches, at $15.6 \%$ (5 nos.) a thorough pedestrian guard rails (with minimum $1500 \mathrm{~mm}$ height and clear visibility is existent.

Among the surveyed thirty-two stretches, Storm Water Drains are present in $90.6 \%$ (29 nos.). Except in one stretch, Storm Water Drains are working at 87.50\% (28 nos.).

Only one (3.13\%) Public Toilet is present in the surveyed stretch, and it is in working condition.

Trash Bins are present in $12.5 \%$ (4 nos.) of the surveyed stretches. Except in one stretch, Trash Bins are working in 9.4\% (3 nos.) stretches. These municipal garbage bins are away from the line of pedestrian flow in $12.5 \%$ (4 nos.) of the surveyed stretch.

Streetlights are present in all thirty-two surveyed stretches. Except for two stretches, Street Lights are working at 93.8\% (30 nos.). In 93.8\% (30 nos.) of the surveyed stretches, the electric poles are neither placed away from the pedestrian flow and nor demarcated with a tactile marking of a minimum of $600 \mathrm{~mm}$ around the poles.

Satisfactory cross-fall satisfactory (i.e., <1:50) is existent in 62.5\% (20 nos.) of the thirty-two surveyed stretches. In addition to this, tactile paving is not present in any of the surveyed stretches. $75 \%$ (24 nos.) among the thirty-two surveyed stretches do not have anti-skid/ matt finish tiles in the footpath and kerb.

Although Manholes are present in each of the thirty-two surveyed stretches. The 'drain type' manholes are flushed with the pavement surface in $87.5 \%$ (28 nos.). In $71.9 \%$ (23 nos.) of the thirty-two surveyed stretches, the 'grating' type manholes are sited away from the respective pedestrian walkway.

In $71.9 \%$ (23 nos.), Kerb alongside surveyed stretches is observed. Among the thirtytwo surveyed stretches, the Kerb is not at a height of more than $150 \mathrm{~mm}$ from the road in $75 \%$ (24 nos.). Additionally, in 93.8\% (30 nos.) of the surveyed stretches, the Kerb ramps present in the stretches neither have a minimum width of $1200 \mathrm{~mm}$ width nor have tactile warning. In relation to this, a cornered Kerb radius of more than $6 \mathrm{~m}$ is present in none of the thirty-two surveyed stretches.

'At-grade' pedestrian crossing (MID-BLOCK crossing) at intersections along the walkway is present in all the thirty-two surveyed stretches since the delineation of survey stretches was made by fragmenting the footpath from one end of a street's entrance till the entrance of the next street. However, Signalized Crossings are existent in 50\% (16 nos.) of the thirty-two surveyed stretches. Except in one stretch, Signalized Stretches are working at $46.89 \%$ (15 nos.). Audio Signals are not present in 96.9\% (31 nos.) of the surveyed stretches.

In $34.4 \%$ (11 nos.) of the surveyed stretches, street furniture is present. Additionally, in $25 \%$ ( 8 nos.) of the stretches, the street furniture has knee clearance of a minimum of $700 \mathrm{~mm}$ and wheelchair space of $1000 \mathrm{~mm}$.

In similar lines, the stretches neither have Fire Hydrant, nor Security Cameras.

In all the thirty-two surveyed stretches, additional inclusive features like Street Signage, Bicycle Track, and Bicycle Track are absent. However, Street Art is present in one $(3.1 \%)$ of the surveyed stretch.

Figure 5-12 shows some issues from the survey photographed by the authors. 


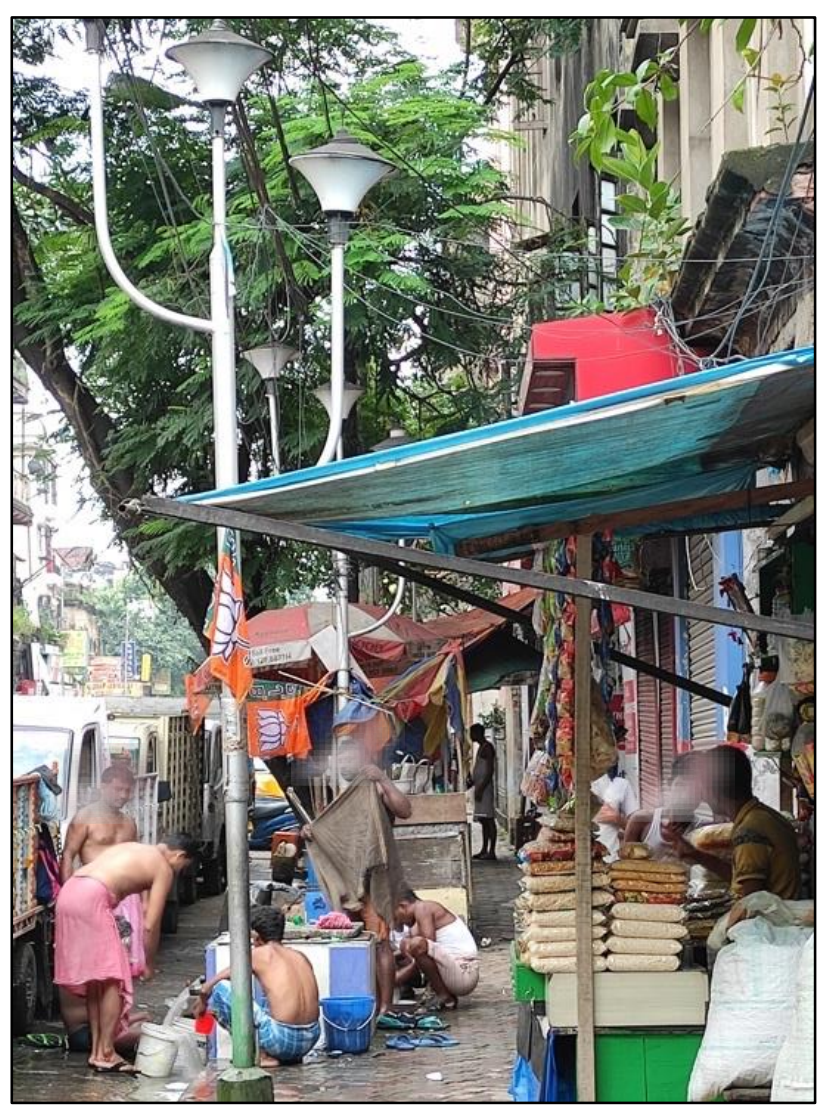

Figure 5: Public Open Bath

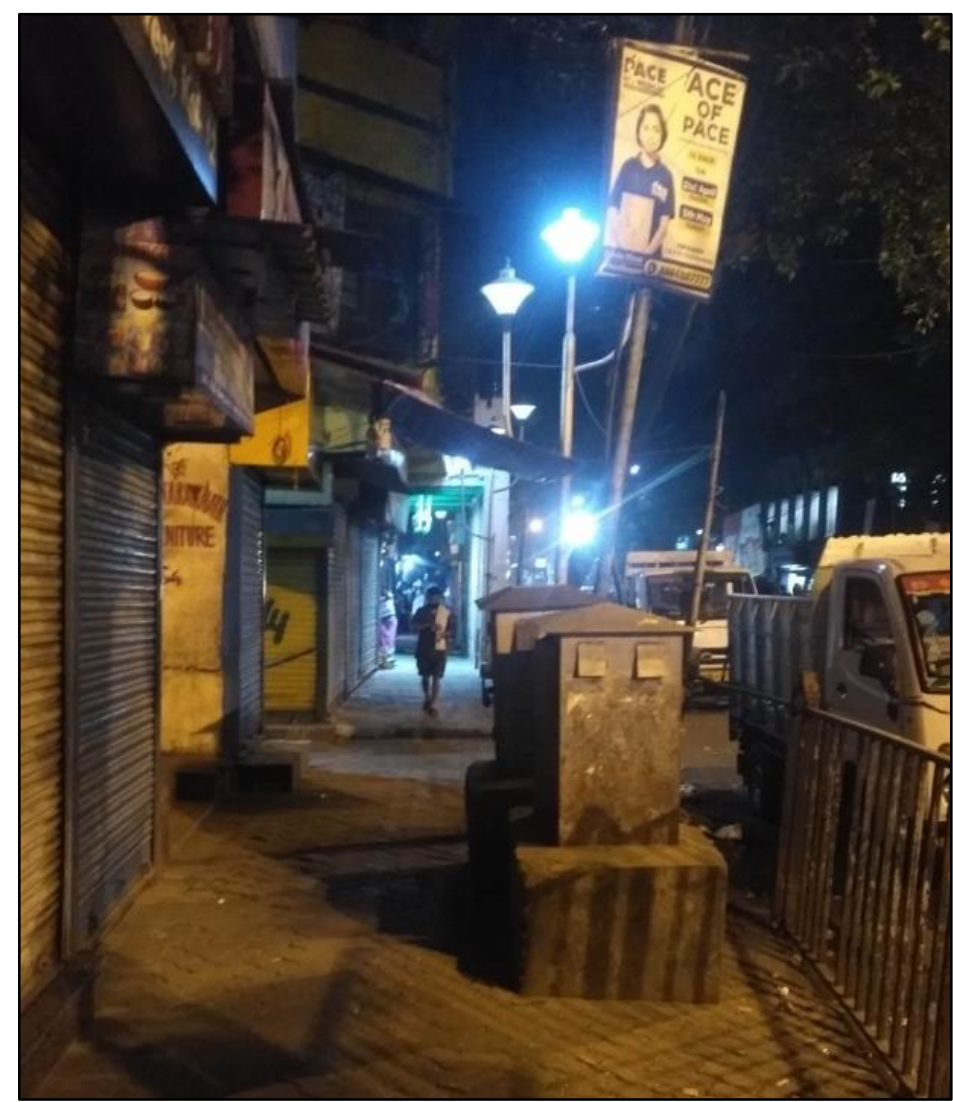

Figure 6: Obstruction within the footpath

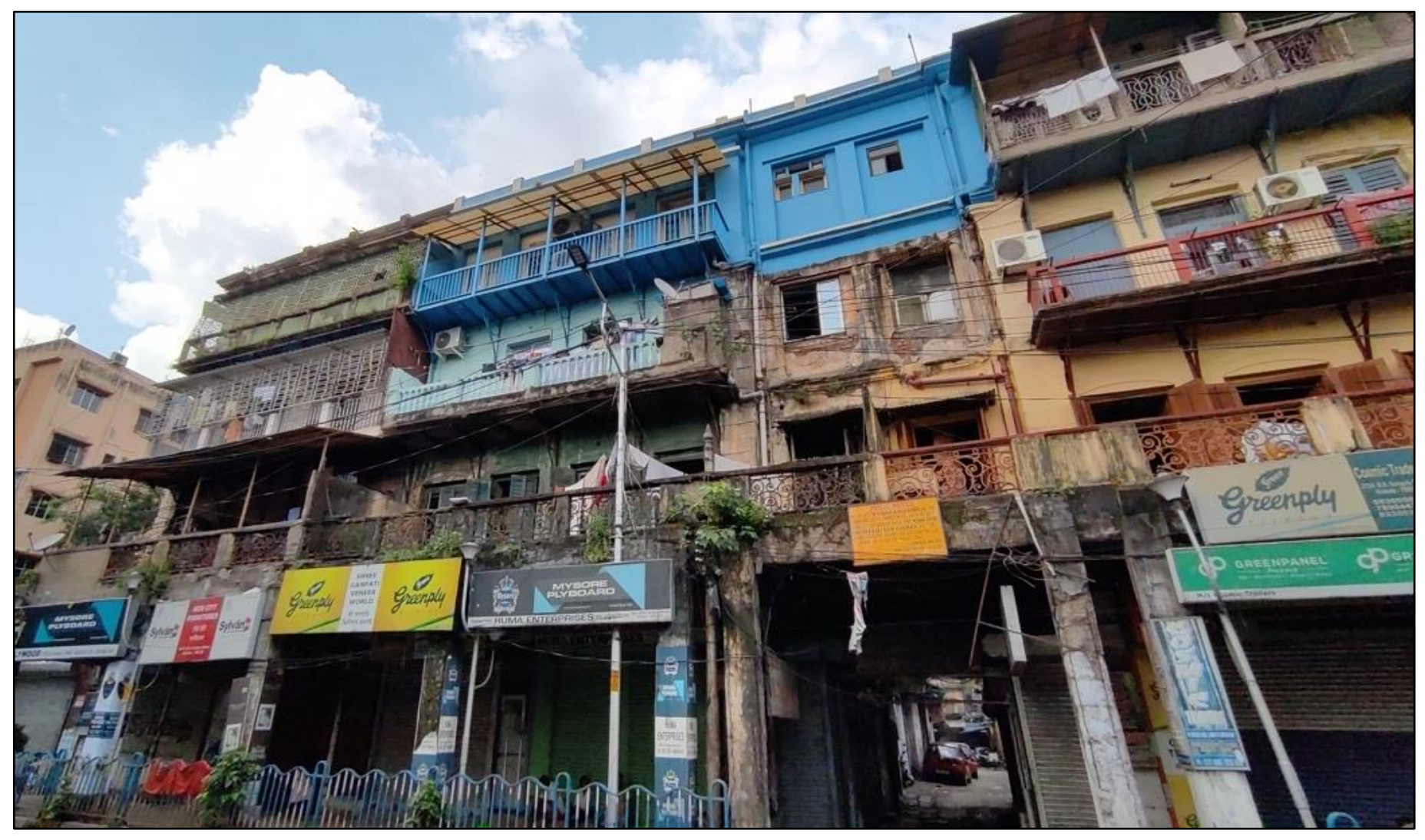

Figure 7: Mixed Use Buildings (Ground: Commercial; Upper Floors: Residential). 


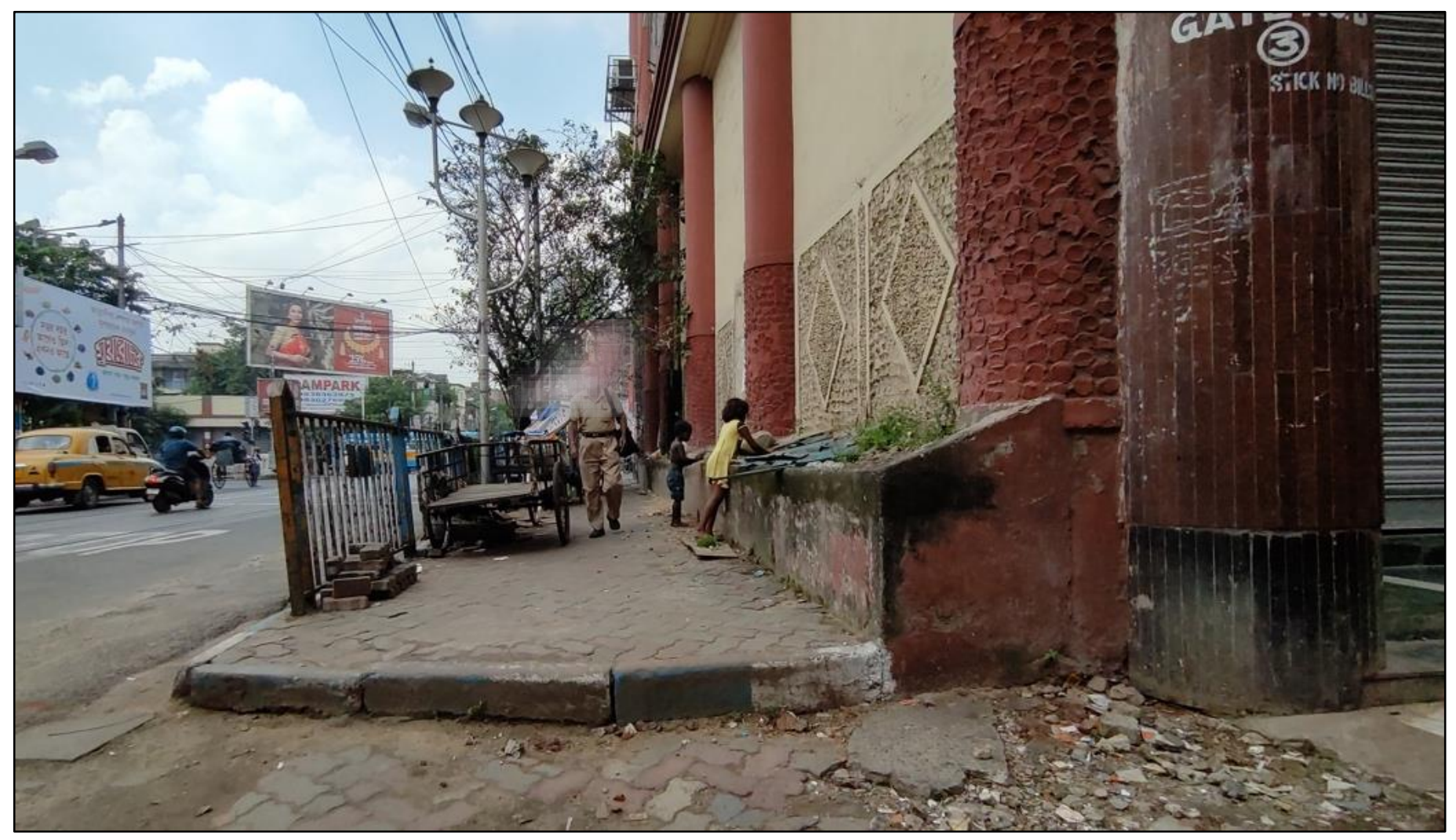

Figure 8: Footpath height improper for differently-abled people.

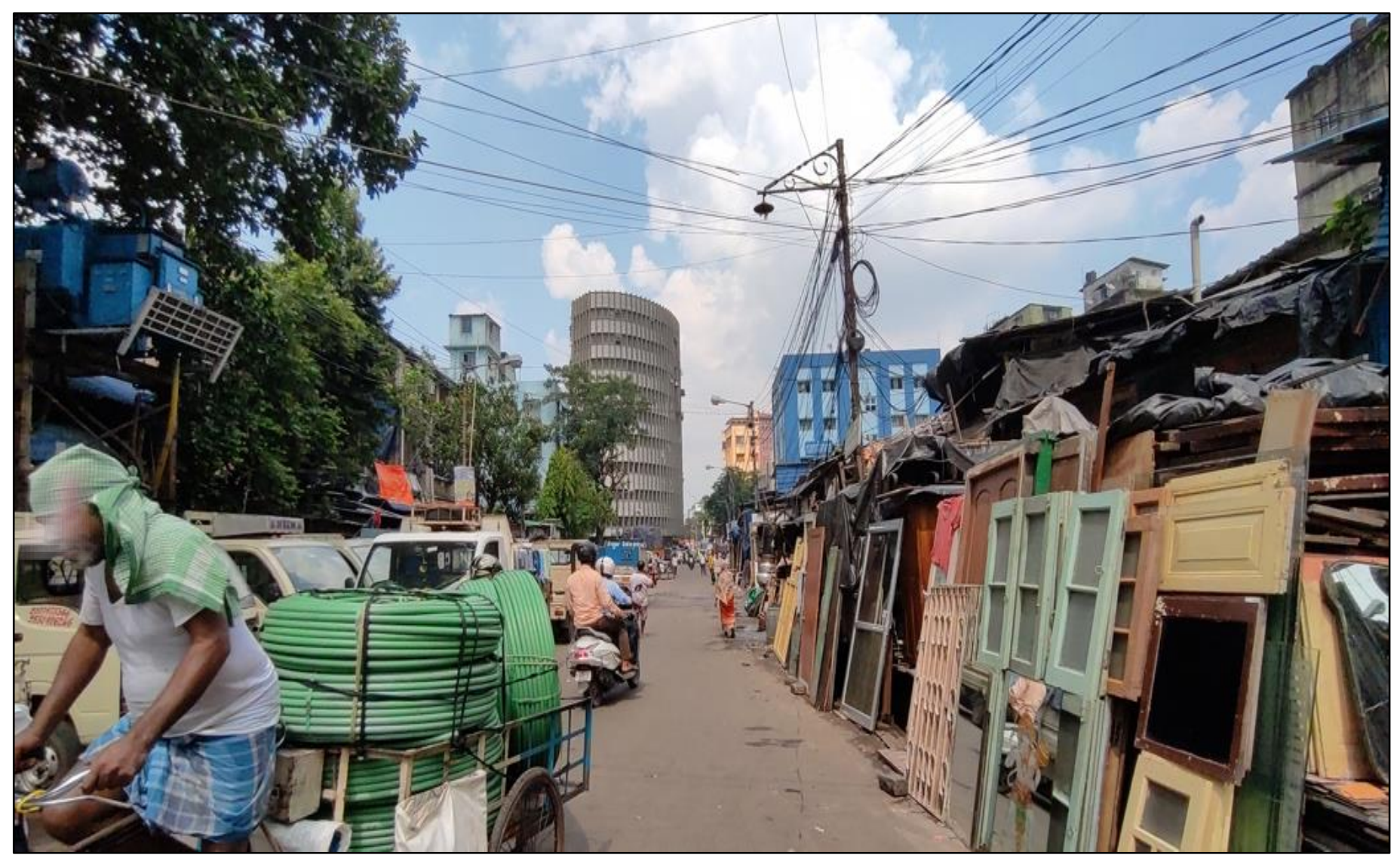

Figure 9: Footpaths (and railings) blocked by the encroachment. 


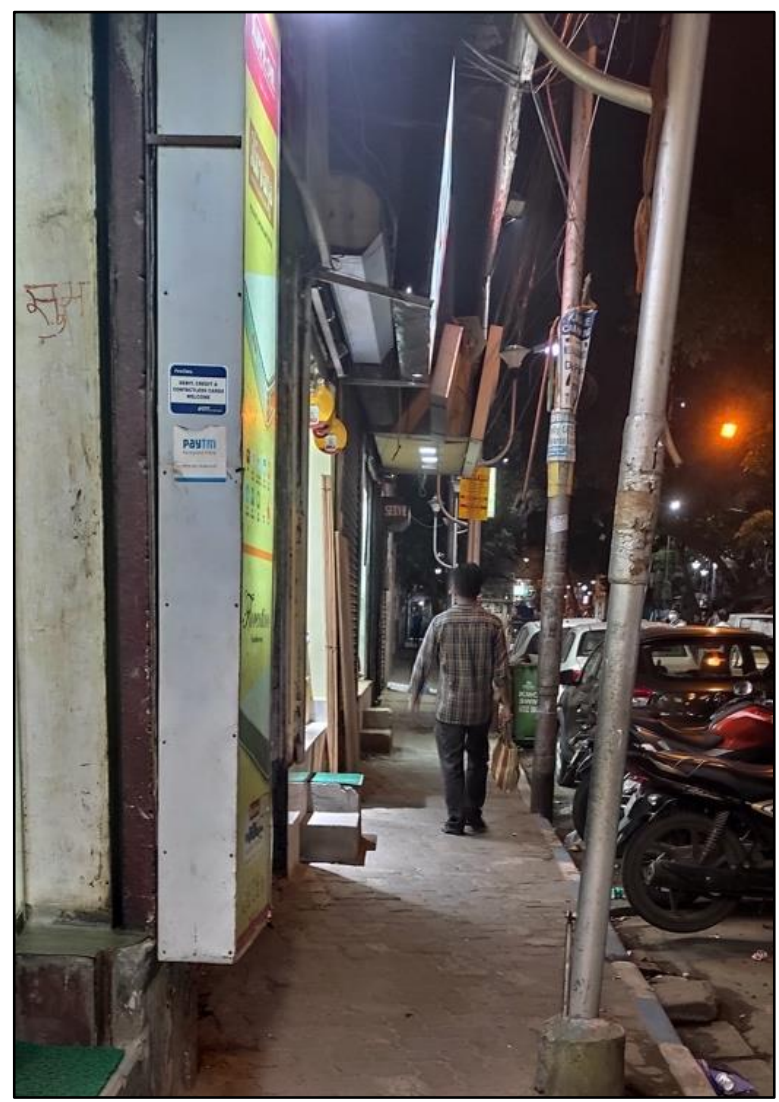

Figure 10: Street Lights inside footpath

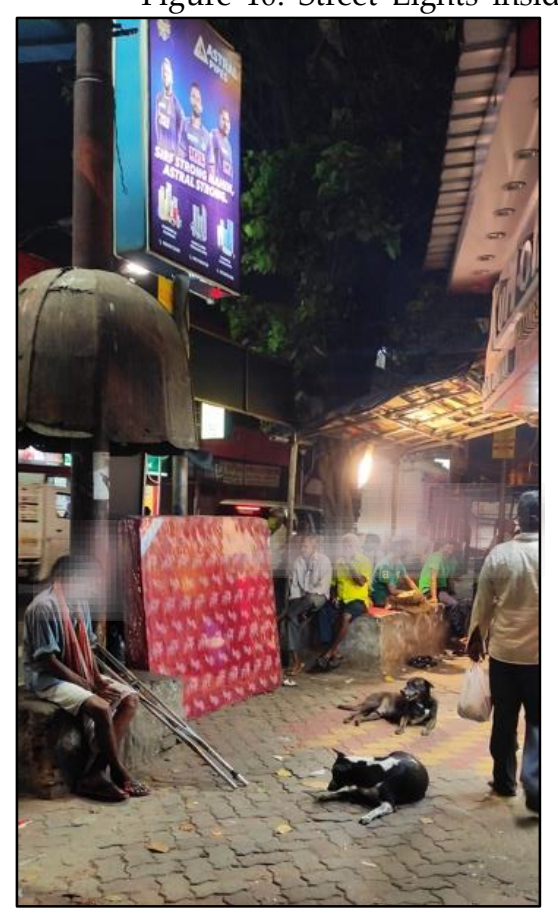

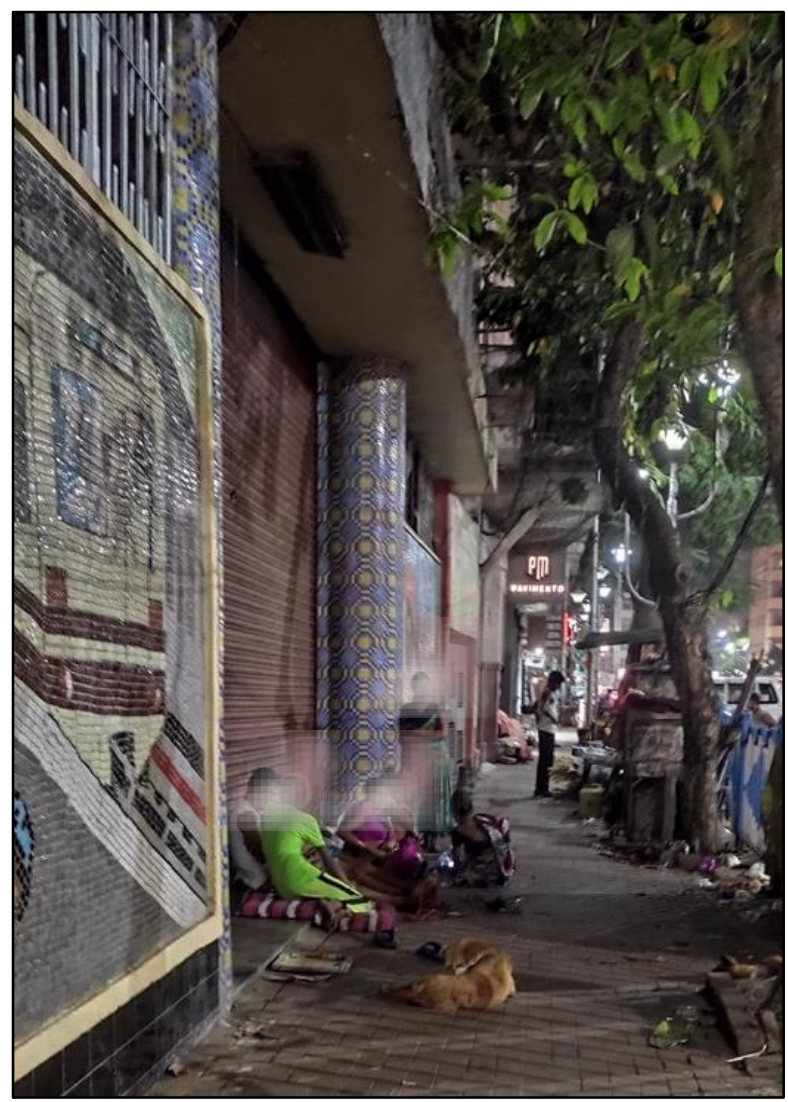

Figure 11: Closed Metro Gates used by beggars
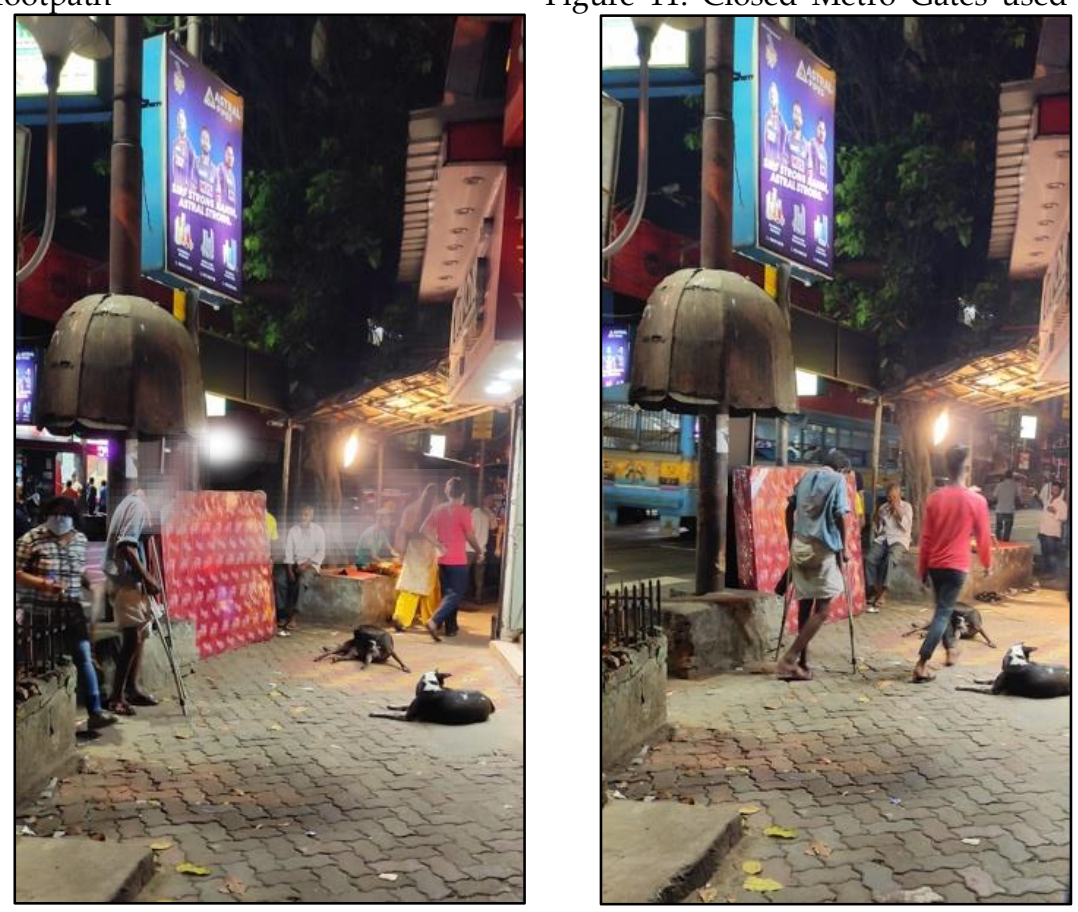

Figure 12: Observing Differently Abled person in the case area [Source for Figure 5-12: Author].

\section{Discussions}


This section of the research starts with tabulating "Total achieved score of sub-criteria across all thirty-two surveyed stretches" divided by "Maximum Achievable Score of each sub-criterion", as shown in Figure 13.

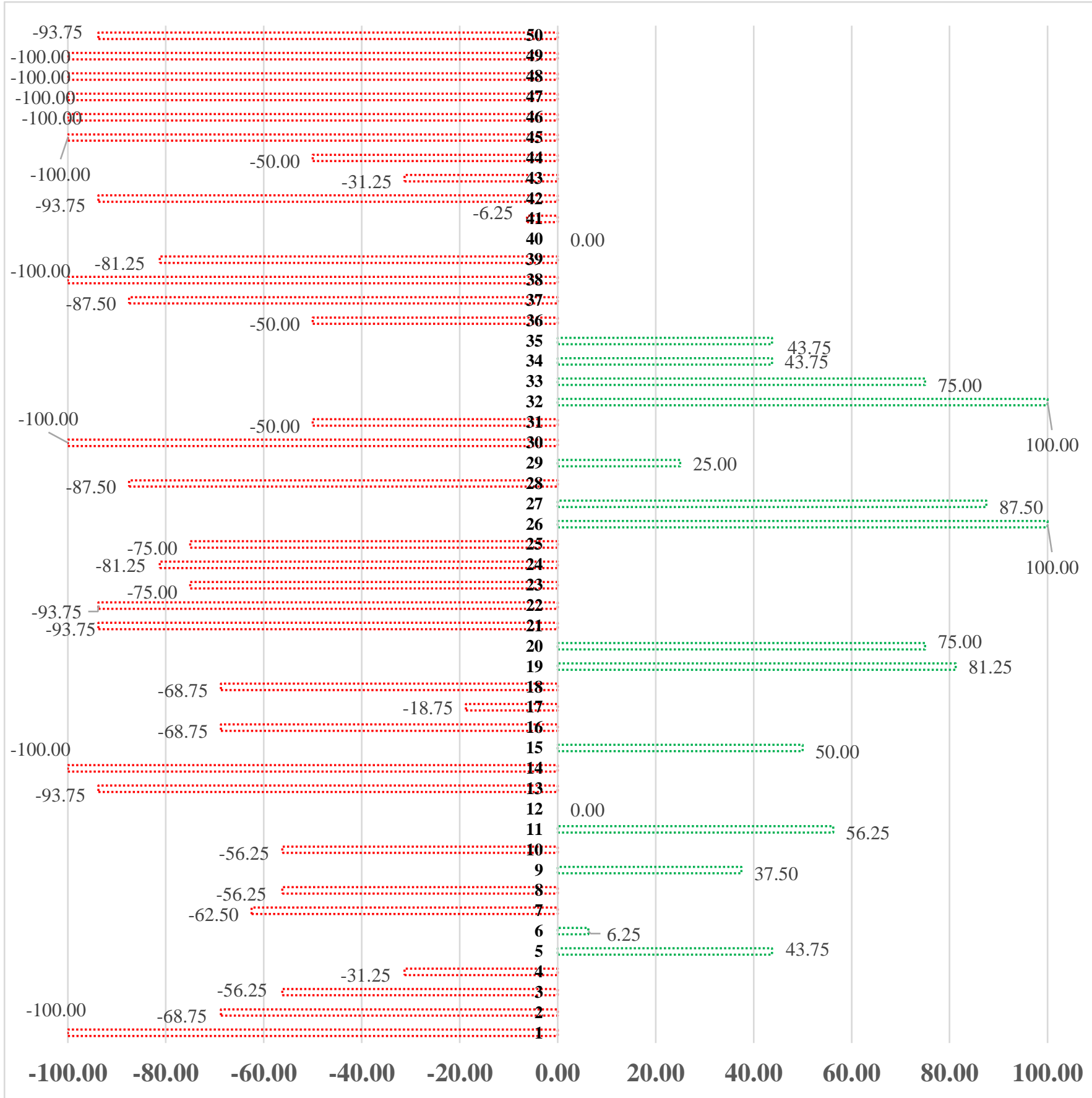

Figure 13: Conditions of the sub-criteria in the case area. The sub-criteria (1-50) are as mentioned in Appendix 4 [Source: Author]

Based on the aforementioned figure (Figure 13), the percentage score of the fifty subcriterion can be segregated into three domains- Positive, Neutral or zero, and Negative. Out of fifty sub-criterion, $68 \%$ (34 nos.) are in the negative domain suggesting weak infrastructural conditions in the case area. In addition to this as much as nine $(18 \%)$ of the subcriteria bears negative $100 \%$ score. Furthermore, in two (4\%), the score is zero, suggesting the gap in ideal accessibility conditions. The remaining ( $28 \%$ or 14 nos.) are in the positive domain. Among the fourteen sub-criterion in positive domain, only two (4\%) are having positive $100 \%$ presence. 
In addition to this, based on the aforesaid observations, the thirty-two surveyed stretches were scored as per the methodology elaborated in Appendix 4. As explained within Segment 4 of this paper and in Appendix 4, for any study stretch surveyed using the framework used for this research, the consolidated highest score can be twenty (and subsequently, the lowest can be -20). In relation to this, none of the thirty-two surveyed stretches in this research have a positive score. Individual score for each of the thirty-two stretches in response to the eighteen criteria (and respective sub-criteria) is mentioned in Appendix 6.

Along these lines, the inferences from the survey prove that the case area has considerably weak pedestrian conditions. Thus, the hypothesis considered for this research holds true. The approach towards improving the conditions (by city authorities) can be prioritised in two patterns:

1) Precinct based approach (on the basis of the percentage score of the sub-criterion across all the surveyed stretches): The sub-criterion having negative score in negative percentage score requires prioritized attention in terms of infrastructural intervention, followed by the sub-criterion bearing zero percentage score and the ones bearing negative percentage score respectively. So, within a particular precinct, each sub-criterion shall be developed in a sequential order. However, pertaining to the contextual constraints of old cities (like unchangeable footpath widths, or occasional street vendors), the aim of city authorities should be to reach as much score as possible.

2) Case-Based approach (on the basis of score of the individual surveyed stretch evaluated using the research framework): The stretches with lowest score can be prioritized while taking up infrastructural assignments. Each stretch can be improved as much as possible (based on the specific context) before taking up the next stretch.

\subsection{Scope for further research}

Based on the findings from this research, the authors recommend an Accessibility Audit format for assessing the degree of accessibility in the walkability conditions of old core cities of India. Keeping coherence with the audit format used in this research for mapping "Infrastructural Conditions", a "weightage" is added to the survey format for further study in old core Indian cities. Out of a total $100 \%$ weightage, $97.5 \%$ is distributed across the eighteen criteria (including the fifty sub-criteria) and an additional $2.5 \%$ is kept flexible for contextual factors (like topography, harsh climate, and likewise). In the context of old Indian cities, the contextual factors might refer to potholes, etc. Thus, while using the survey format in different old Indian cities (other than the case area of Kolkata), the contextual factor shall vary.

It is to be noted that the Mean value of the respective sub-criteria is considered as the percentage score for a Criterion. The weightage allocation is based on the percentage score of each Criterion (as shown in Figure 13), where Criteria with:

(1) 0 to $50 \%$ is allocated $20 \%$ weightage,

(2) $50 \%$ to $100 \%$ is allocated $10 \%$ weightage,

(3) $-50 \%$ to 0 is allocated $5 \%$ weightage, and

(4) -100 to $-50 \%$ is allocated $2.5 \%$ weightage.

The logic used in allocating the weightage is: criterion with more percentage is predominant in the old core areas, and conversely, criterion with least (or negative) percentage is more suited for an "ideal" accessibility condition. The term "ideal" represents the conditions referred to in Indian guidelines (proposed by likes of Indian Road Congress) as best suited for pedestrian comfort. Figure 14 shows the proposed accessibility audit format with associated weightage for each criterion. 


\section{ACCESSIBILITY AUDIT FORMAT FOR OLD CORE INDIAN CITIES $\quad$ SHEET 01}

Date : $\_l l \_$City

/ Ward Number : _ / Lat. Lon. :

Time: __ _ $\overline{\mathrm{AM} / \mathrm{PM}}$ Name of the Stretch : Stretch Width :

(1) Building Typology of Stretch Weightage: $2.5 \%$

a) Buildings that are having 'two or more' building uses within a single building $\square$ YES $\square$ NO

b) Heritage/ historic buildings

$\square$ YES $\square$ NO

(2) Footpath Dimension

Weightage: $5 \%$

a) Footpath Width $>2500 \mathrm{~mm}$

$\square$ YES $\square$ NO

b) Unobstructed width of $1800 \mathrm{~mm}$

$\square$ YES $\square$ NO

c) Unobstructed clear height of $2200 \mathrm{~mm}$ $\square$ YES $\square$ NO

(3) Temporary Encroachment

Weightage: $5 \%$

a) Unorganized Informal Vendors functional during day/ night

$\checkmark$ YES $\square$ NO

b) Unorganized Informal Vendors/ hawkers away from the line of pedestrian flow

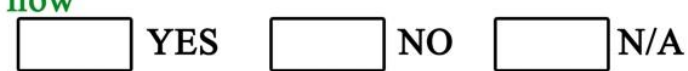

c) Beggar/ homeless/ child labour occupying a part of the footpath as their homes

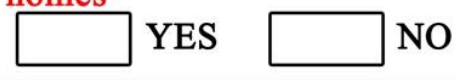

(4) Permnanent Encroachment Weightage: 10\%

a) Place of religious interest (temple/ churches/ mosque) within or along the footpath

\begin{tabular}{|l}
\hline YES \\
b) 'Encroachment'
\end{tabular}
establishments on to the footpath $\square$ YES $\square$ NO

c) 'Communal open bath' within or along the footpath

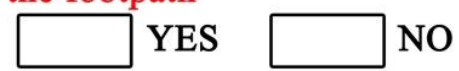

Name of Surveyor :

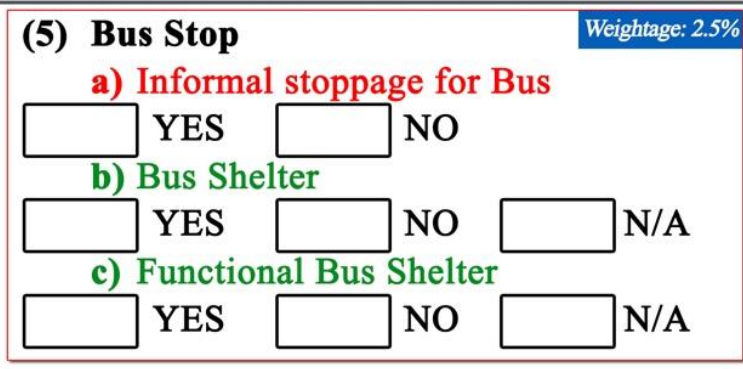

(6) Metro Rail Entrance

a) Entrance connected to the footpath YES $\square$ NO

b) Functional Metro Rail Entrance

YES $\square$ NO $\square$ N/A

(7) Railings (pedestrian guard rails)

Weightage: $5 \%$

a) Railings on the edge of the footpath

$\square$ YES $\square$ NO

b) Thorough railings with minimum $1500 \mathrm{~mm}$ height and clear visibility

$\longrightarrow$ YES $\square$ NO $\square$ N/A

(8) Storm Water Drains

Weightage: $20 \%$

a) Storm Water Drains along footpath

$\square$ YES $\square$ NO

b) Functional Storm Water Drains

$\square$ YES $\square$ NO $\square$ N/A

(9) Public Toilet (Restroom) Weightage: $2.5 \%$

a) Public Toilet within the footpath

YES $\longrightarrow$ NO

b) Functional Public Toilet

YES $\square$ NO $\square$ N/A

(10) Trash Bins $\quad$ Weightage: $2.5 \%$

a) Trash Bins within the footpath YES $\square$ NO

b) Functional Trash Bins YES $\square$ NO $\square$ N/A

c) Trash Bins located away from line of pedestrian flow $\square$ YES $\square$ NO $\square$ N/A

/ Supervised by : 
ACCESSIBILITY AUDIT FORMAT FOR OLD CORE INDIAN CITIES $\quad$ SHEET 02

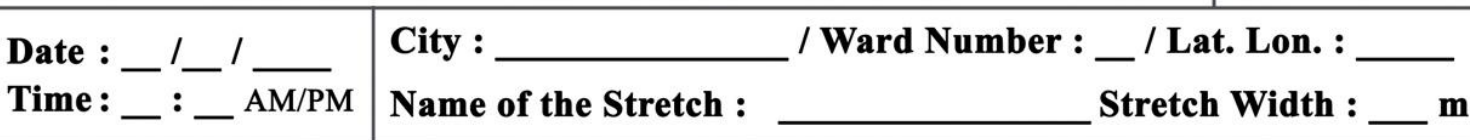

(11) Street Lights $\quad$ Weightage: $2.5 \%$

a) Street Lights within the footpath

$\square$ YES $\square$ NO

b) Functional Street Lights

YES $\square$ NO $\square$ N/A

c) Light Poles away from pedestrian flow or if present, is demarcated with a tactile marking of a minimum $600 \mathrm{~mm}$ around it

$\square$ YES $\square$ NO $\square$ N/A

(12) Flooring

Weightage: $5 \%$

a) Satisfactory Cross Fall (i.e. <1:50)

$\square$ YES $\square$ NO

b) Tactile Marking

YES $\longrightarrow$ NO

c) Anti-skid/ matt finish tiles in footpath and kerb

YES $\square$ NO

(13) Manholes

Weightage: $10 \%$

a) Manholes within/ along the footpath

$\square$ YES $\square$ NO

b) 'Drain type' manholes flushed with the pavement surface

$\square$ YES

c) 'Grating type' manholes sited away from the pedestrian walkway

$\square$ YES $\square$ NO $\square$ N/A

(14) Kerb

Weightage: $5 \%$

a) Kerb on the edge of footpath

$\square$ YES $\square$ NO

b) Kerb Height $<150 \mathrm{~mm}$ from road level

$\square$ YES $\square$ NO $\square$ N/A

c) Minimum $1200 \mathrm{~mm}$ width and tactile warning

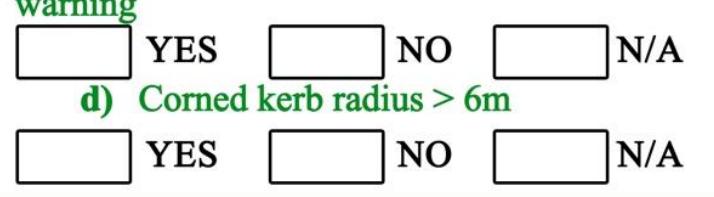

Name of Surveyor :
(15) Pedestrian Crossing

Weightage: $5 \%$

a) 'At-grade' pedestrian crossing (MID-BLOCK crossing) at all intersections along the walkway

$\square$ YES $\square$ NO

b) Signalized Intersection

$\square$ YES $\square$ NO $\square$ N/A

c) Functional Signalized Intersection

\begin{tabular}{|c|c|c|c|}
\hline & YES & NO & N/A \\
\hline d) & udio $\mathrm{S}$ & & \\
\hline & YES & NO & N/A \\
\hline
\end{tabular}

\begin{tabular}{l|l} 
(16) Street Furniture $\quad$ Weightage: $5 \%$
\end{tabular}

a) Street Furniture in the footpath

$\square$ YES $\square$ NO

b) Street furniture having a knee clearance of a minimum of $700 \mathrm{~mm}$ and wheelchair space of $1000 \mathrm{~mm}$

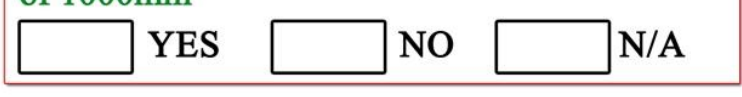

\begin{tabular}{l|l}
\hline (17) Safety and Security & Weightage: $2.5 \%$
\end{tabular}

a) Fire Hydrant

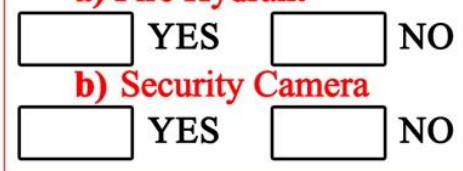

(18) Additional Inclusive features Weightage: $2.5 \%$

a) Signage

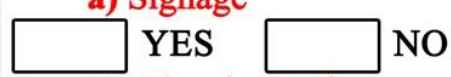

b) Bicycle Track

YES NO

c) Public Drinking Water Facility

$\longrightarrow$ YES $\square$ NO

d) Street Art

YES $\square$ NO

\begin{tabular}{ll} 
(19) Contextual Factors $\quad$ Weightage: $2.5 \%$ \\
\hline
\end{tabular}

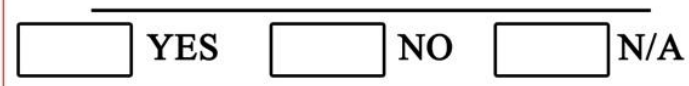

/ Supervised by :

Figure 14: Accessibility Audit Format for Old Core Cities in India [Source: Author].

[N.B.: In Figure 14, = Independent Variable, $=$ Dependent Variable] 
The authors propose the following model (Figure 15) for further research.

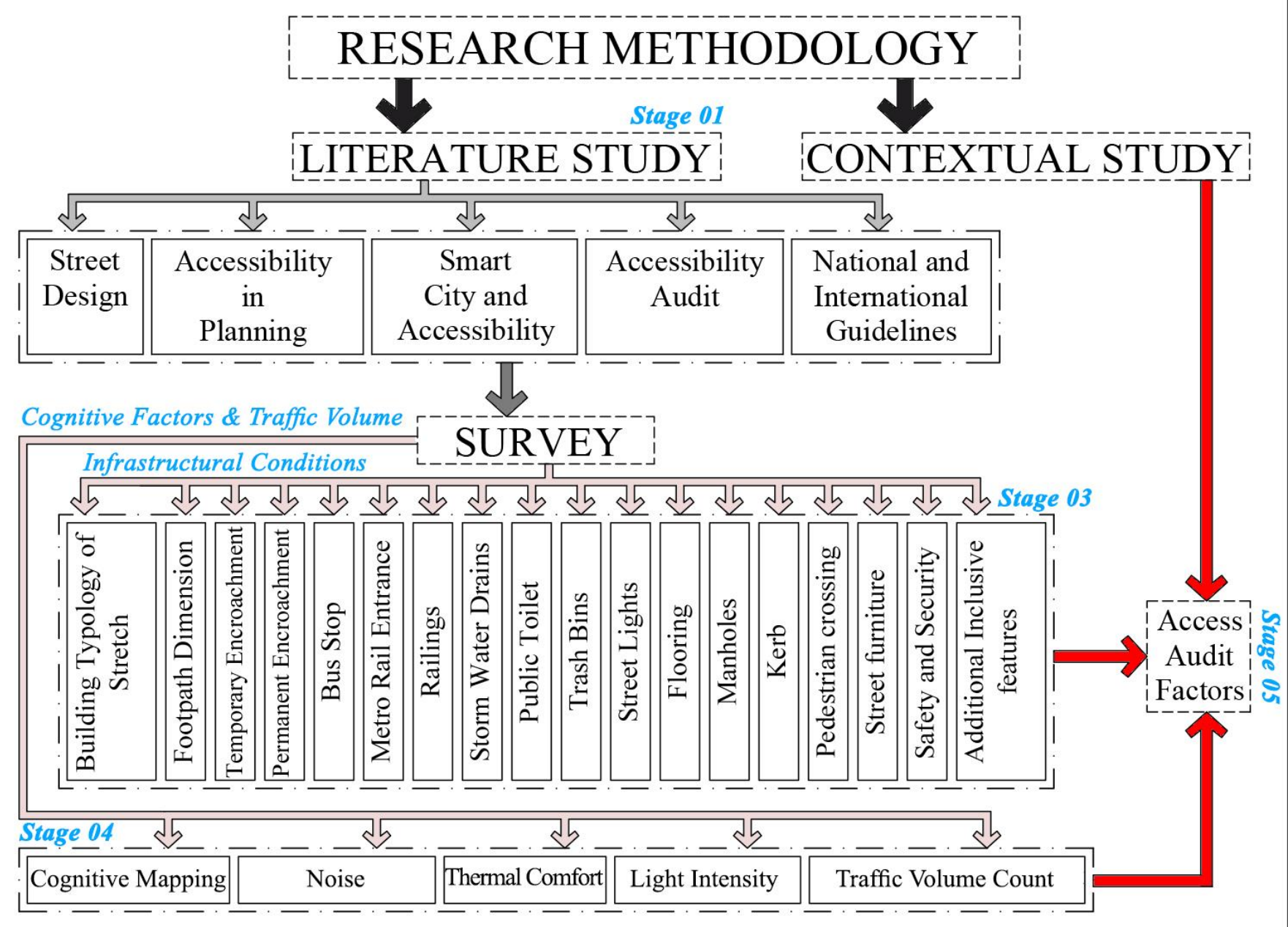

Figure 15: Research Methodology for further research [Source: Author].

In relation to Figure 15, Stage 01 to Stage 03 has been covered in this paper; however, the authors suggest that Stage 04 might strengthen the formation of an Accessibility Audit format for old cities in India. The authors further elaborate on Stage 04:

\subsubsection{Cognitive Factors:}

Cognitive considerations are the key to the successful Universal Design solution. Similarly, the feedback of the intended user group for the Universal Design solution needs a heterogeneous treatment for research analysis [82]. The "Cognitive Factors" segment is composed of two parts: Cognitive Mapping, and subsequently three continuous variables: 1) Noise (Sound Intensity measured in Decibel), 2) Light Intensity (measured in Lux), and 3) Thermal Comfort (Temperature measured in degree Centigrade).

The Cognitive mapping can help in understanding the convenience to walk by assessing the travel distance and time. As an initiation, the authors have started to conduct surveys in Hokkaido University campus involving a prosthetic suit which induces a scenario of elderly physical condition when worn by individuals. The individuals are asked to walk a certain distance with and without the prosthetic suit during same time on a single day/ night. Figure 16 shows some instances from the research. 

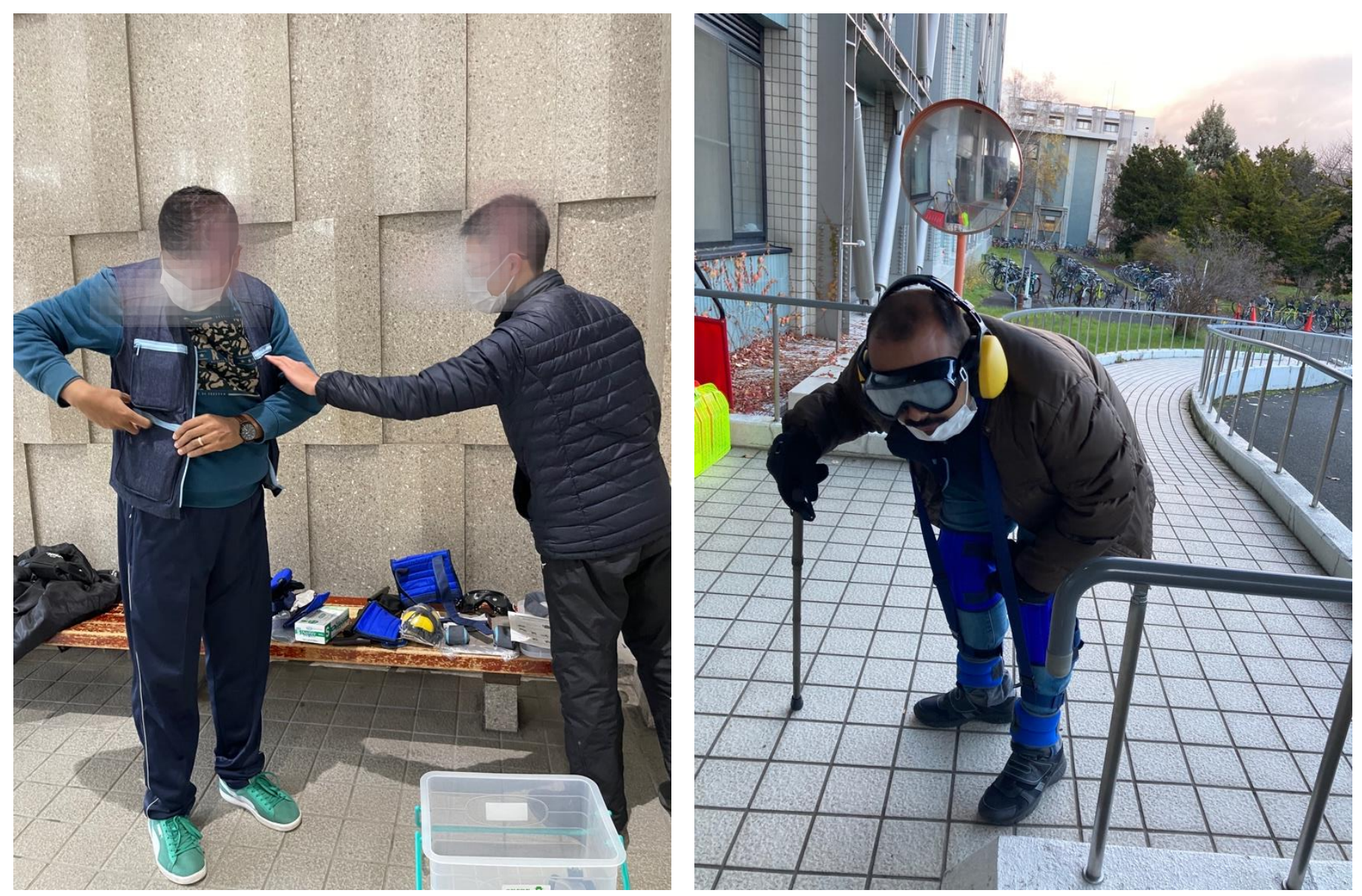

Figure 16: Authors conducting research for further explorations in the similar research area

For assessing the continuous variables (Noise, Light Intensity, and Thermal Comfort), the type of questionnaire to be used for this survey is Structured Open-Ended. During the survey, multiple measurements (across different seasons, and different times of the day) should be taken for ensuring Reliability Ethics. A suggestive "Online Google Form" used for this survey is available online at https://forms.gle/iRRS9ZMQu9GY2yt98 (accessed on 26th May 2021). Additionally, collaborative (authors and end-users) cognitive maps can be useful.

\subsubsection{Traffic Volume Count:}

The "Traffic Volume Count" is composed of an independent variable: Number of Pedestrians during peak hour. Successive measurements (across different seasons, different times of the day, different days of the week, and during festivals) must be taken for ensuring Reliability Ethics.

Furthermore, these two factors "Cognitive Factors" and "Traffic Volume Count" can be related to the Accessibility Score in walkability scenarios (which has been furnished in this paper).

\subsection{Impact of this research}

Indian cities have multiplicity in administrative settings and an inherently complex Social Model of disability. However, from the perspective of APR, the technical aspect of Accessibility can be addressed suitably. After understanding the need of people with functional limitations (from the Medical Model) and the appropriateness of infrastructure requirements (from the Social Model), the Technical Model can be proposed as shown in Figure 17. 


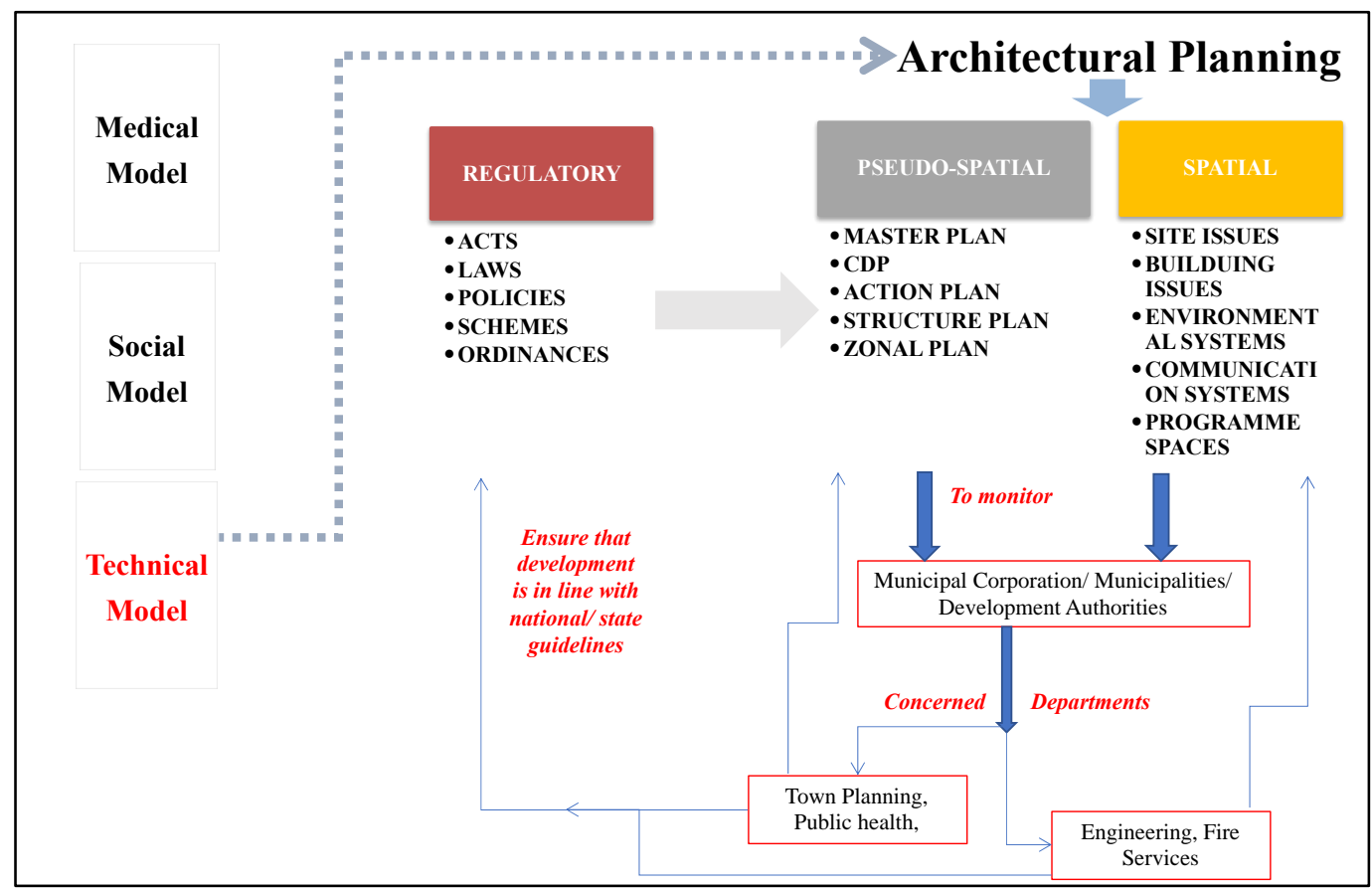

Figure 17: Role of APR in imparting Accessibility in Old Core Indian Cities [Source: Author].

Responsibility for ensuring Accessibility in Old Core Cities allocated to Specific departments in the Urban/ Municipal administrative setting shall enhance the chances of making citizen-friendly pedestrian streetscape. This process, in turn, shall also ensure the realization of UN-SDG Number 11: Sustainable Cities and Communities.

The famous statement by Frank Chimero "People ignore design that ignores People" holds true for describing the case area in this research. The historically rich core of Kolkata is in the decaying stage since the case area is less suitable for human mobility (at pedestrian level). Furthermore, Architectural Planning Research (APR) might be an important tool to approach accessibility-related assessments or interventions, in old core Indian cities.

The authors are part of the "Laboratory of Architectural Planning", Hokkaido University, Japan. The "Laboratory of Architectural Planning" prioritizes exploring next-generation planning theory that contributes to global well-being. In relation to this, some objectives of this laboratory are noteworthy:

Objective 2.1: Environmental Design that realizes safe and comfortable going out for the physically vulnerable, and

Objective 4.1: Daily movement of people and spatial perception/ cognition.

In previous publications from the "Laboratory of Architectural Planning", the different typologies of walkability in Asian context have been investigated from multiple perspectives [78]; including local mixed-use streets [79]. Especially, the re-development strategy of old streets in the Asian context has been contextually evaluated in this laboratory [80] [81]. Thus, the authors suggest scopes for further research in the same domain in coherence with their affiliated laboratory.

Finally, the authors state that the theoretical, ideological, and methodological learnings from this paper can be referred to by researchers for further investigation on accessibility issues in old core Indian cities.

Author Contributions: Conceptualization, S.M. and G.D.M.; methodology, G.D.M.; software, G.D.M.; validation, S.M. and R.N.; formal analysis, G.D.M.; investigation, G.D.M.; resources, S.M., R.N. and G.D.M.; data curation, G.D.M.; writing - original draft preparation, G.D.M.; writing - review and editing, S.M. and R.N.; visualization, G.D.M.; supervision, S.M. and R.N.; project administration, S.M. and R.N.; funding acquisition, S.M. All authors have read and agreed to the published version of the manuscript. 
Funding: This research received no external funding.

Data Availability Statement: Ethical review and approval were waived for this study, since no data and information related to the ethical guidelines were at the discretion of the committee at Hokkaido University.

Acknowledgments: The authors gratefully acknowledge the help of the people who accompanied them during survey in Kolkata, India:

1. Ms. Soumyasree Chakraborty ( Soumyasreechakraborty19@gmail.com),

2. Ms. Disha Maity (dishamaiti@gmail.com),

3. Mr. Akash Das (dasakash0710@gmail.com), and

4. Mr. Sagnik Das (sagnikdas565@gmail.com).

Conflicts of Interest: The authors declare no conflict of interest.

\section{Appendix 1}

Census Map prepared in 1913 by E.P. Richards; Published by Jennings \& Bewley. [Source: Curiosity Collections, Harvard Library; This map is a part of the Census map for entire Kolkata 
available at https:/curiosity.lib.harvard.edu/scanned-maps/catalog/44-990114901360203941 accessed on 28th May 2021]

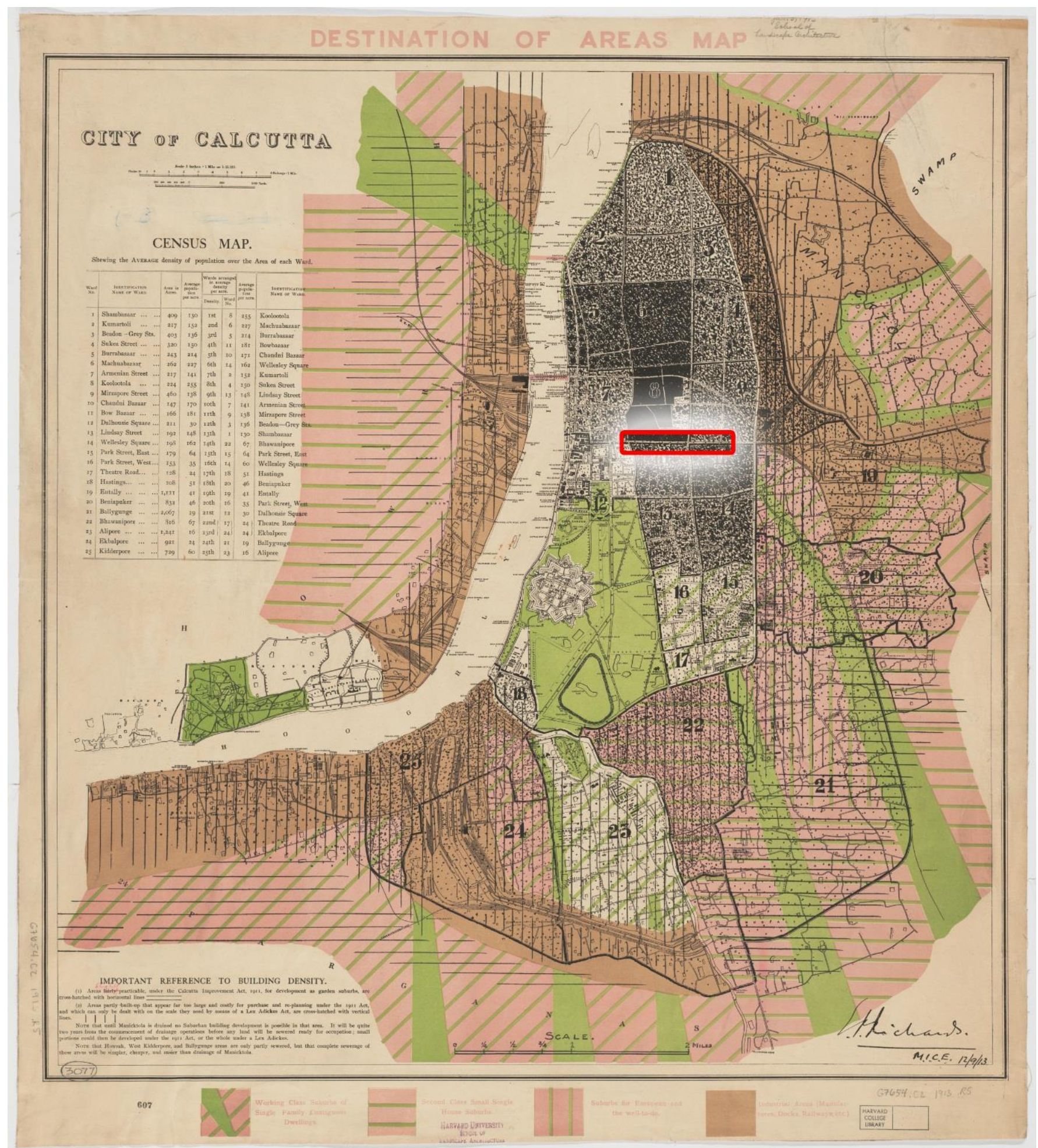

The study area for this paper is highlighted in red. The table on the top left represents the density of different neighbourhoods in Kolkata.

\section{Appendix 2}

Classified Traffic Volume Count at Peak Hour in three junctions 


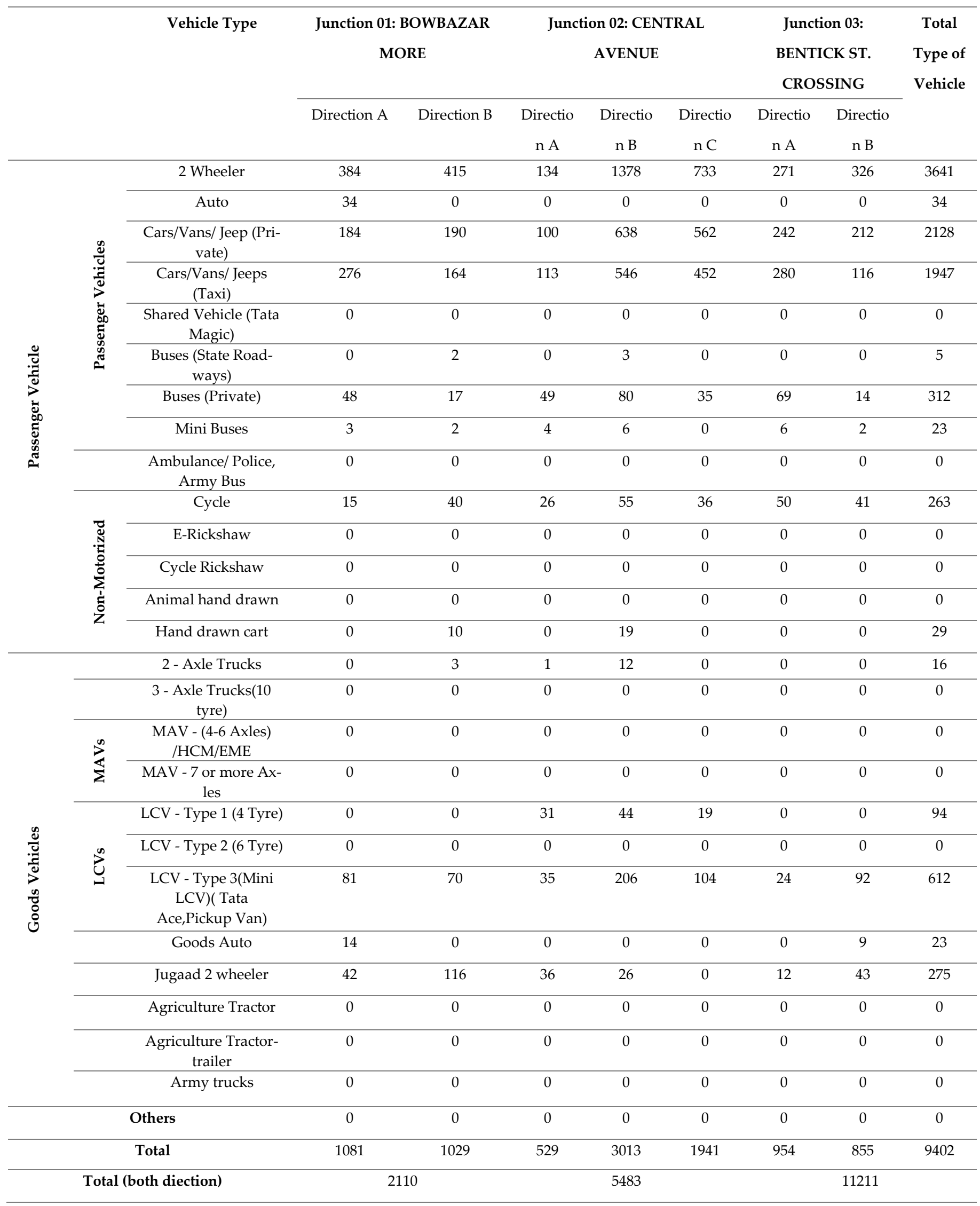

Appendix 3

Indian guidelines related to disability and inclusiveness (Source: Author) 


\begin{tabular}{|c|c|c|c|}
\hline S.No. & YEAR & INDIAN GUIDELINES & IMPLEMENTING AGENCY \\
\hline 1 & 1950 & Constitution of India, Article 15 & Government of India \\
\hline 2 & 1968 & $\begin{array}{l}\text { IS 4963: Recommendations for Buildings and Facili- } \\
\text { ties for the Physically Handicapped } \\
\text { (Revised in 1987) }\end{array}$ & $\begin{array}{l}\text { Bureau of Indian Standards (Ministry of Housing } \\
\text { and Urban Affairs) }\end{array}$ \\
\hline 3 & 1970 & $\begin{array}{l}\text { National Building Code of India } \\
\text { (Revised in 1983, 2005, 2016) }\end{array}$ & Bureau of Indian Standards \\
\hline 4 & 1983 & $\begin{array}{l}\text { IS 7419: Requirements for stairs for physical reha- } \\
\text { bilitation (First Revision) }\end{array}$ & Bureau of Indian Standards \\
\hline 5 & 1987 & The Mental Health Act & $\begin{array}{c}\text { Legislative Department, Ministry of Law and Jus- } \\
\text { tice }\end{array}$ \\
\hline 6 & 1991 & $\begin{array}{l}\text { IS 8086: Rehabilitation equipment - Wheelchairs, } \\
\text { folding, junior size - Specification (First Revision) }\end{array}$ & Bureau of Indian Standards \\
\hline 7 & 1992 & $\begin{array}{c}\text { Rehabilitation Council of India Act } \\
\text { (Amended in 2000) }\end{array}$ & Ministry of Law Justice and Company Affairs \\
\hline 8 & 1995 & $\begin{array}{c}\text { Persons with Disabilities (Equal Opportunities, } \\
\text { Protection of Rights and Full Participation) Act (Re- } \\
\text { placed in } 2017 \text { after RPwD Act) }\end{array}$ & $\begin{array}{c}\text { Department of Empowerment of Persons with dis- } \\
\text { abilities, Ministry of Social Justice and Empower- } \\
\text { ment }\end{array}$ \\
\hline 9 & 1997 & $\begin{array}{l}\text { Rehabilitation Council of India (Standards of Pro- } \\
\text { fessional Conduct, Etiquette and Code of Ethics for } \\
\text { Rehabilitation Professionals) Regulations } \\
\text { (Revised in 1998) }\end{array}$ & $\begin{array}{c}\text { Department of Empowerment of Persons with dis- } \\
\text { abilities, Ministry of Social Justice and Empower- } \\
\text { ment }\end{array}$ \\
\hline
\end{tabular}

\begin{tabular}{|c|c|c|c|}
\hline 10 & 1998 & $\begin{array}{l}\text { Guidelines and Space standards for Barrier Free } \\
\text { Built Environment for Disabled and Elderly per- } \\
\text { sons }\end{array}$ & $\begin{array}{l}\text { Central Public Works Department, Ministry of Ur- } \\
\text { ban Affairs and Employment, }\end{array}$ \\
\hline 11 & 1999 & $\begin{array}{c}\text { The National Trust for Welfare of Persons with Au- } \\
\text { tism, Cerebral Palsy, Mental Retardation and Mul- } \\
\text { tiple Disability Act }\end{array}$ & $\begin{array}{l}\text { Legislative Department, Ministry of Law, Justice } \\
\text { and Company Affairs }\end{array}$ \\
\hline 12 & 2000 & $\begin{array}{l}\text { The National Trust for Welfare of Persons with Au- } \\
\text { tism, Cerebral Palsy, Mental Retardation and Mul- } \\
\text { tiple Disability Rules } \\
\text { (Amended in 2010, 2015) }\end{array}$ & Ministry of Social Justice and Empowerment \\
\hline 13 & 2001 & $\begin{array}{l}\text { The National Trust for Welfare of Persons with Au- } \\
\text { tism, Cerebral Palsy, Mental Retardation and Mul- } \\
\text { tiple Disability Regulations }\end{array}$ & Ministry of Social Justice and Empowerment \\
\hline 14 & 2001 & $\begin{array}{c}\text { Board of Trust Regulations } \\
\text { (Amended in 2004, 2006, 2010, 2017) }\end{array}$ & $\begin{array}{c}\text { Department of Empowerment of Persons with dis- } \\
\text { abilities, Ministry of Social Justice and Empower- } \\
\text { ment }\end{array}$ \\
\hline 15 & 2001 & Planning a Barrier Free Environment & $\begin{array}{l}\text { Office of the Chief Commissioner, People with } \\
\text { Disability }\end{array}$ \\
\hline 16 & 2006 & National Policy for Persons with Disabilities & Ministry of Social Justice and Empowerment \\
\hline 17 & 2009 & $\begin{array}{l}\text { National Action Plan on Business and Human } \\
\text { Rights }\end{array}$ & Ministry of Corporate Affairs \\
\hline 18 & 2012 & Guidelines for Pedestrian Facilities (IRC: 103-2012) & Indian Roads Congress \\
\hline 19 & 2012 & Manual on Disability Statistics & $\begin{array}{c}\text { Central Statistics Office, Ministry of Statistics and } \\
\text { Programme Implementation }\end{array}$ \\
\hline 20 & 2014 & Handbook of Barrier Free and Accessibility & Central Public Works Department \\
\hline 21 & 2014 & The Rights of Persons with Disabilities Bill & $\begin{array}{l}\text { Legislative Department, Ministry of Law and Jus- } \\
\text { tice }\end{array}$ \\
\hline 22 & 2015 & Accessible India Campaign & $\begin{array}{c}\text { Department of Empowerment of Persons with } \\
\text { Disabilities, Ministry of Social Justice and Empow- } \\
\text { erment }\end{array}$ \\
\hline 23 & 2015 & $\begin{array}{l}\text { First Country Report on the Status of Disability in } \\
\text { India }\end{array}$ & $\begin{array}{c}\text { Department of Empowerment of Persons with } \\
\text { Disabilities, Ministry of Social Justice and Empow- } \\
\text { erment }\end{array}$ \\
\hline
\end{tabular}


(Submitted in pursuance of Article 35 of the UN

Convention on the Rights of Persons with Disabili-

ties)

\begin{tabular}{|c|c|c|c|}
\hline 24 & 2016 & $\begin{array}{l}\text { Harmonised guidelines and space standards for } \\
\text { Barrier Free Built Environment for People with Dis- } \\
\text { ability and Elderly Persons }\end{array}$ & Ministry of Urban Development \\
\hline 25 & 2016 & $\begin{array}{l}\text { The Rights to Persons with Disability (RPwD) Act, } \\
\text { Gazette (dated 28.12.2016) }\end{array}$ & Ministry of Law and Justice \\
\hline 26 & 2016 & Elderly in India & $\begin{array}{c}\text { Social Statistics Division, Central Statistics Office, } \\
\text { Ministry of Statistics and Programme Implemen- } \\
\text { tation }\end{array}$ \\
\hline 27 & 2016 & Disabled persons in India- A Statistical Profile & $\begin{array}{c}\text { Social Statistics Division, Ministry of Statistics and } \\
\text { Programme Implementation }\end{array}$ \\
\hline 28 & 2017 & $\begin{array}{l}\text { Rights of Persons with Disabilities Rules } \\
\text { (Amended 2020) }\end{array}$ & $\begin{array}{c}\text { Department of Empowerment of Persons with dis- } \\
\text { abilities, Ministry of Social Justice and Empower- } \\
\text { ment }\end{array}$ \\
\hline 29 & 2017 & $\begin{array}{l}\text { Parallel Report of India on the Convention on the } \\
\text { Rights of Persons with Disabilities (CRPD) }\end{array}$ & $\begin{array}{l}\text { National Disability Network (NDN) and National } \\
\text { Committee on the Rights of Persons with Disabili- } \\
\text { ties (NCRPD) }\end{array}$ \\
\hline 30 & 2019 & $\begin{array}{c}\text { CPWD Works Manual } 2019 \text { (including Standard } \\
\text { Operating Procedures) }\end{array}$ & Central Public Works Department \\
\hline 31 & 2020 & $\begin{array}{l}\text { Building Accessible, Safe, and Inclusive Indian Cit- } \\
\text { ies (BASIIC) }\end{array}$ & $\begin{array}{c}\text { National Institute of Urban Affairs (NIUA) in col- } \\
\text { laboration with Ministry of Housing and Urban } \\
\text { Affairs (MoHUA) }\end{array}$ \\
\hline
\end{tabular}

\section{Appendix 4}

Variables (Criteria and Sub-Criteria), Types of Variables (Independent/ Dependent), Scoring Logic, and the Individual Scores (Source: Author)

\begin{tabular}{|c|c|c|c|c|c|c|}
\hline \multirow[t]{2}{*}{ S.No } & \multirow[t]{2}{*}{ Criterion } & \multirow[t]{2}{*}{ Sub Criterion } & \multirow[t]{2}{*}{ Variable Type } & \multirow[t]{2}{*}{ Marking logic } & \multicolumn{2}{|c|}{ Score } \\
\hline & & & & & If Yes & If No \\
\hline \multirow[t]{2}{*}{1} & \multirow{2}{*}{$\begin{array}{l}\text { Building Ty- } \\
\text { pology of } \\
\text { Stretch }\end{array}$} & $\begin{array}{l}\text { Buildings that are having 'two or more' } \\
\text { building uses within a single building }\end{array}$ & Independent & $\begin{array}{l}\text { Beneficial if } \\
\text { Absent }\end{array}$ & +0.50 & -0.50 \\
\hline & & Heritage/ historic buildings & Independent & $\begin{array}{l}\text { Beneficial if } \\
\text { Absent }\end{array}$ & +0.50 & -0.50 \\
\hline \multirow[t]{3}{*}{2} & \multirow[t]{3}{*}{$\begin{array}{l}\text { Footpath Di- } \\
\text { mension }\end{array}$} & Footpath Width $>2500 \mathrm{~mm}$ & Independent & $\begin{array}{l}\text { Beneficial if } \\
\text { Present }\end{array}$ & +0.50 & -0.50 \\
\hline & & Unobstructed width of $1800 \mathrm{~mm}$ & Independent & $\begin{array}{l}\text { Beneficial if } \\
\text { Present }\end{array}$ & +0.50 & -0.50 \\
\hline & & Unobstructed clear height of $2200 \mathrm{~mm}$ & Independent & $\begin{array}{l}\text { Beneficial if } \\
\text { Present }\end{array}$ & +0.50 & -0.50 \\
\hline \multirow[t]{3}{*}{3} & \multirow[t]{3}{*}{$\begin{array}{c}\text { Temporary } \\
\text { Encroachment }\end{array}$} & $\begin{array}{l}\text { Unorganized Informal Vendors func- } \\
\text { tional during day/ night }\end{array}$ & Independent & $\begin{array}{c}\text { Beneficial if } \\
\text { Absent }\end{array}$ & +0.50 & -0.50 \\
\hline & & $\begin{array}{l}\text { Unorganized Informal Vendors/ hawkers } \\
\text { away from the line of pedestrian flow (if } \\
\text { Vendors are present) }\end{array}$ & Dependent & $\begin{array}{l}\text { Beneficial if } \\
\text { Present }\end{array}$ & +0.25 & -0.25 \\
\hline & & $\begin{array}{l}\text { Beggar/ homeless/ child labour occupy- } \\
\text { ing a part of the footpath as their homes }\end{array}$ & Independent & $\begin{array}{l}\text { Beneficial if } \\
\text { Absent }\end{array}$ & +0.50 & -0.50 \\
\hline \multirow[t]{3}{*}{4} & \multirow[t]{3}{*}{$\begin{array}{l}\text { Permanent En- } \\
\text { croachment }\end{array}$} & $\begin{array}{l}\text { Place of religious interest (temple/ } \\
\text { churches/ mosque) within or along the } \\
\text { footpath? }\end{array}$ & Independent & $\begin{array}{l}\text { Beneficial if } \\
\text { Absent }\end{array}$ & +0.50 & -0.50 \\
\hline & & $\begin{array}{l}\text { 'Encroachment' by existing establish- } \\
\text { ments on to the footpath }\end{array}$ & Independent & $\begin{array}{l}\text { Beneficial if } \\
\text { Absent }\end{array}$ & +0.50 & -0.50 \\
\hline & & $\begin{array}{l}\text { 'Communal open bath' within or along } \\
\text { the footpath }\end{array}$ & Independent & $\begin{array}{c}\text { Beneficial if } \\
\text { Absent }\end{array}$ & +0.50 & -0.50 \\
\hline
\end{tabular}




\begin{tabular}{|c|c|c|c|c|c|c|}
\hline \multirow[t]{3}{*}{5} & \multirow[t]{3}{*}{ Bus Stop } & Informal stoppage for Bus & Independent & $\begin{array}{c}\text { Beneficial if } \\
\text { Absent }\end{array}$ & +0.50 & -0.50 \\
\hline & & Bus Shelter (if Bus Stops) & Dependent & $\begin{array}{c}\text { Beneficial if } \\
\text { Present }\end{array}$ & +0.25 & -0.25 \\
\hline & & $\begin{array}{l}\text { Is 'Bus Shelter' functional (if Bus Shelter } \\
\text { is present) }\end{array}$ & Dependent & $\begin{array}{c}\text { Beneficial if } \\
\text { Present }\end{array}$ & +0.25 & -0.25 \\
\hline \multirow[t]{2}{*}{6} & \multirow[t]{2}{*}{$\begin{array}{l}\text { Metro Rail En- } \\
\quad \text { trance }\end{array}$} & Entrance connected to the footpath & Independent & $\begin{array}{l}\text { Beneficial if } \\
\text { Absent }\end{array}$ & +0.50 & -0.50 \\
\hline & & $\begin{array}{l}\text { Is the Entrance functional (if Metro Rail } \\
\text { Entrance is present) }\end{array}$ & Dependent & $\begin{array}{l}\text { Beneficial if } \\
\text { Present }\end{array}$ & +0.25 & -0.25 \\
\hline \multirow[t]{2}{*}{7} & \multirow[t]{2}{*}{ Railings } & $\begin{array}{l}\text { Railings (pedestrian guard rails) on the } \\
\text { edge of the footpath }\end{array}$ & Independent & $\begin{array}{c}\text { Beneficial if } \\
\text { Present }\end{array}$ & +0.50 & -0.50 \\
\hline & & $\begin{array}{l}\text { Thorough railings with minimum } \\
\text { 1500mm height and clear visibility (if } \\
\text { Railings are present) }\end{array}$ & Dependent & $\begin{array}{l}\text { Beneficial if } \\
\text { Present }\end{array}$ & +0.25 & -0.25 \\
\hline \multirow[t]{2}{*}{8} & \multirow[t]{2}{*}{$\begin{array}{l}\text { Storm Water } \\
\text { Drains }\end{array}$} & Storm Water Drains along footpath & Independent & $\begin{array}{l}\text { Beneficial if } \\
\text { Present }\end{array}$ & +0.50 & -0.50 \\
\hline & & $\begin{array}{c}\text { Functional Storm Water Drains (if Storm } \\
\text { Water Drains are present) }\end{array}$ & Dependent & $\begin{array}{l}\text { Beneficial if } \\
\text { Present }\end{array}$ & +0.25 & -0.25 \\
\hline \multirow[t]{2}{*}{9} & \multirow[t]{2}{*}{$\begin{array}{l}\text { Public Toilet } \\
\text { (Restroom) }\end{array}$} & Public Toilet within the footpath & Independent & $\begin{array}{l}\text { Beneficial if } \\
\text { Present }\end{array}$ & +0.50 & -0.50 \\
\hline & & $\begin{array}{l}\text { Functional Public Toilet (if Public Toilet } \\
\text { is present) }\end{array}$ & Dependent & $\begin{array}{l}\text { Beneficial if } \\
\text { Present }\end{array}$ & +0.25 & -0.25 \\
\hline \multirow[t]{3}{*}{10} & \multirow[t]{3}{*}{ Trash Bins } & Trash Bins within the footpath & Independent & $\begin{array}{l}\text { Beneficial if } \\
\text { Present }\end{array}$ & +0.50 & -0.50 \\
\hline & & $\begin{array}{c}\text { Functional Trash Bins (if Trash Bins are } \\
\text { present) }\end{array}$ & Dependent & $\begin{array}{l}\text { Beneficial if } \\
\text { Present }\end{array}$ & +0.25 & -0.25 \\
\hline & & $\begin{array}{l}\text { Trash Bins located away from the line of } \\
\text { pedestrian flow (if Trash Bins present) }\end{array}$ & Dependent & $\begin{array}{l}\text { Beneficial if } \\
\text { Present }\end{array}$ & +0.25 & -0.25 \\
\hline \multirow[t]{3}{*}{11} & \multirow[t]{3}{*}{ Streetlights } & Streetlights within the footpath & Independent & $\begin{array}{l}\text { Beneficial if } \\
\text { Present }\end{array}$ & +0.50 & -0.50 \\
\hline & & $\begin{array}{l}\text { Functional Street Lights (if Street Lights } \\
\text { are present) }\end{array}$ & Dependent & $\begin{array}{l}\text { Beneficial if } \\
\text { Present }\end{array}$ & +0.25 & -0.25 \\
\hline & & $\begin{array}{l}\text { Light Poles away from pedestrian flow or } \\
\text { if present, is demarcated with a tactile } \\
\text { marking of a minimum } 600 \mathrm{~mm} \text { around it } \\
\text { (if Street Lights are present) }\end{array}$ & Dependent & $\begin{array}{l}\text { Beneficial if } \\
\text { Present }\end{array}$ & +0.25 & -0.25 \\
\hline \multirow[t]{3}{*}{12} & \multirow[t]{3}{*}{ Flooring } & Satisfactory Cross Fall (i.e. $<1: 50$ ) & Independent & $\begin{array}{c}\text { Beneficial if } \\
\text { Present }\end{array}$ & +0.50 & -0.50 \\
\hline & & Tactile Marking & Independent & $\begin{array}{c}\text { Beneficial if } \\
\text { Present }\end{array}$ & +0.50 & -0.50 \\
\hline & & $\begin{array}{l}\text { Anti-skid/ matt finish tiles in footpath } \\
\text { and kerb }\end{array}$ & Independent & $\begin{array}{c}\text { Beneficial if } \\
\text { Present }\end{array}$ & +0.50 & -0.50 \\
\hline \multirow[t]{3}{*}{13} & \multirow[t]{3}{*}{ Manholes } & Manholes within/ along the footpath & Independent & $\begin{array}{c}\text { Beneficial if } \\
\text { Present }\end{array}$ & +0.50 & -0.50 \\
\hline & & $\begin{array}{l}\text { Drain type' manholes flushed with the } \\
\text { pavement surface (if Manholes are pre- } \\
\text { sent) }\end{array}$ & Dependent & $\begin{array}{l}\text { Beneficial if } \\
\text { Present }\end{array}$ & +0.25 & -0.25 \\
\hline & & $\begin{array}{c}\text { Grating' type manholes sited away from } \\
\text { the pedestrian walkway (if Manholes are } \\
\text { present) }\end{array}$ & Dependent & $\begin{array}{l}\text { Beneficial if } \\
\text { Present }\end{array}$ & +0.25 & -0.25 \\
\hline \multirow[t]{3}{*}{14} & \multirow[t]{3}{*}{ Kerb } & Kerb on the edge of footpath & Independent & $\begin{array}{c}\text { Beneficial if } \\
\text { Present }\end{array}$ & +0.50 & -0.50 \\
\hline & & $\begin{array}{l}\text { Kerb Height of not more than } 150 \mathrm{~mm} \\
\text { from the road level (if Kerb is present) }\end{array}$ & Dependent & $\begin{array}{l}\text { Beneficial if } \\
\text { Present }\end{array}$ & +0.25 & -0.25 \\
\hline & & $\begin{array}{c}\text { Minimum } 1200 \mathrm{~mm} \text { width and tactile } \\
\text { warning (if Kerb is present) }\end{array}$ & Dependent & $\begin{array}{l}\text { Beneficial if } \\
\text { Present }\end{array}$ & +0.25 & -0.25 \\
\hline
\end{tabular}




\begin{tabular}{|c|c|c|c|c|c|c|}
\hline & & $\begin{array}{l}\text { Corned kerb radius more than } 6 \mathrm{~m} \text { (if } \\
\text { Kerb is present) }\end{array}$ & Dependent & $\begin{array}{l}\text { Beneficial if } \\
\text { Present }\end{array}$ & +0.25 & -0.25 \\
\hline \multirow[t]{4}{*}{15} & \multirow[t]{4}{*}{$\begin{array}{l}\text { Pedestrian } \\
\text { crossing }\end{array}$} & $\begin{array}{l}\text { 'At-grade' pedestrian crossing (MID- } \\
\text { BLOCK crossing) at all intersections } \\
\text { along the walkway }\end{array}$ & Independent & $\begin{array}{l}\text { Beneficial if } \\
\text { Present }\end{array}$ & +0.50 & -0.50 \\
\hline & & $\begin{array}{l}\text { Signalized Intersection (if Crossing is pre- } \\
\text { sent) }\end{array}$ & Dependent & $\begin{array}{l}\text { Beneficial if } \\
\text { Present }\end{array}$ & +0.25 & -0.25 \\
\hline & & $\begin{array}{l}\text { Functional Signalized Intersection (if } \\
\text { Crossing is present) }\end{array}$ & Dependent & $\begin{array}{l}\text { Beneficial if } \\
\text { Present }\end{array}$ & +0.25 & -0.25 \\
\hline & & Audio Signal (if Crossing is present) & Dependent & $\begin{array}{l}\text { Beneficial if } \\
\text { Present }\end{array}$ & +0.25 & -0.25 \\
\hline \multirow[t]{2}{*}{16} & \multirow[t]{2}{*}{$\begin{array}{l}\text { Street furni- } \\
\text { ture }\end{array}$} & Street Furniture in the footpath & Independent & $\begin{array}{c}\text { Beneficial if } \\
\text { Present }\end{array}$ & +0.50 & -0.50 \\
\hline & & $\begin{array}{l}\text { Street furniture having a knee clearance } \\
\text { of a minimum of } 700 \mathrm{~mm} \text { and wheelchair } \\
\text { space of } 1000 \mathrm{~mm} \text { (if Street Furniture is } \\
\text { present) }\end{array}$ & Dependent & $\begin{array}{l}\text { Beneficial if } \\
\text { Present }\end{array}$ & +0.25 & -0.25 \\
\hline \multirow[t]{2}{*}{17} & \multirow[t]{2}{*}{$\begin{array}{l}\text { Safety and Se- } \\
\text { curity }\end{array}$} & Fire Hydrant & Independent & $\begin{array}{l}\text { Beneficial if } \\
\text { Present }\end{array}$ & +0.50 & -0.50 \\
\hline & & Security Camera & Independent & $\begin{array}{l}\text { Beneficial if } \\
\text { Present }\end{array}$ & +0.50 & -0.50 \\
\hline \multirow[t]{5}{*}{18} & \multirow{5}{*}{$\begin{array}{l}\text { Additional In- } \\
\text { clusive fea- } \\
\text { tures }\end{array}$} & Signage & Independent & $\begin{array}{l}\text { Beneficial if } \\
\text { Present }\end{array}$ & +0.50 & -0.50 \\
\hline & & Bicycle Track & Independent & $\begin{array}{l}\text { Beneficial if } \\
\text { Present }\end{array}$ & +0.50 & -0.50 \\
\hline & & Public Drinking Water Facility & Independent & $\begin{array}{l}\text { Beneficial if } \\
\text { Present }\end{array}$ & +0.50 & -0.50 \\
\hline & & Street Art & Independent & $\begin{array}{l}\text { Beneficial if } \\
\text { Present }\end{array}$ & +0.50 & -0.50 \\
\hline & & & \multicolumn{2}{|c|}{ Maximum Total Score } & +20 & -20 \\
\hline
\end{tabular}

\section{Appendix 5}

Survey Format for assessing Infrastructural Conditions in the case area. 
Preprints (www.preprints.org) | NOT PEER-REVIEWED | Posted: 24 December 2021

doi:10.20944/preprints202112.0412.v1

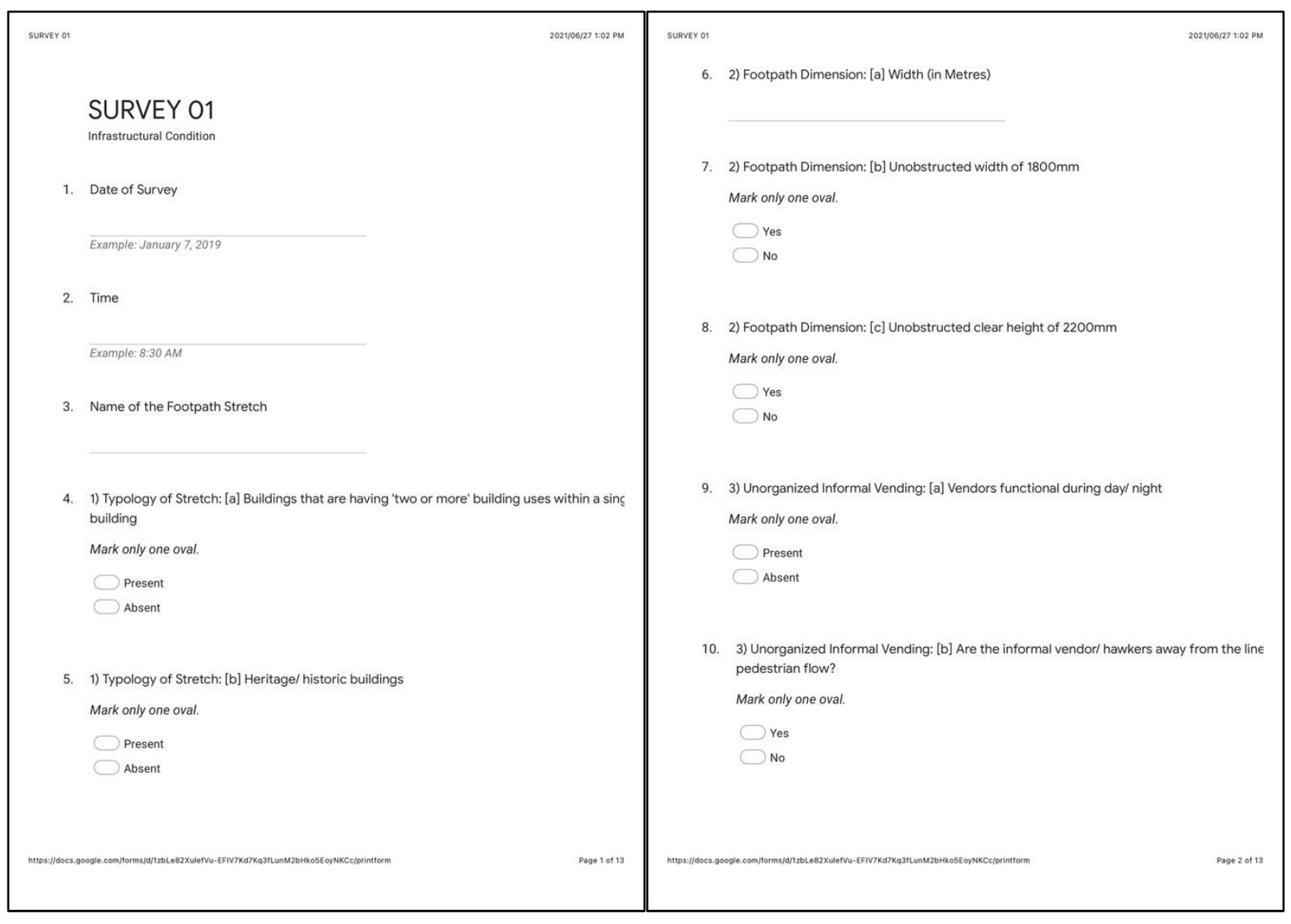

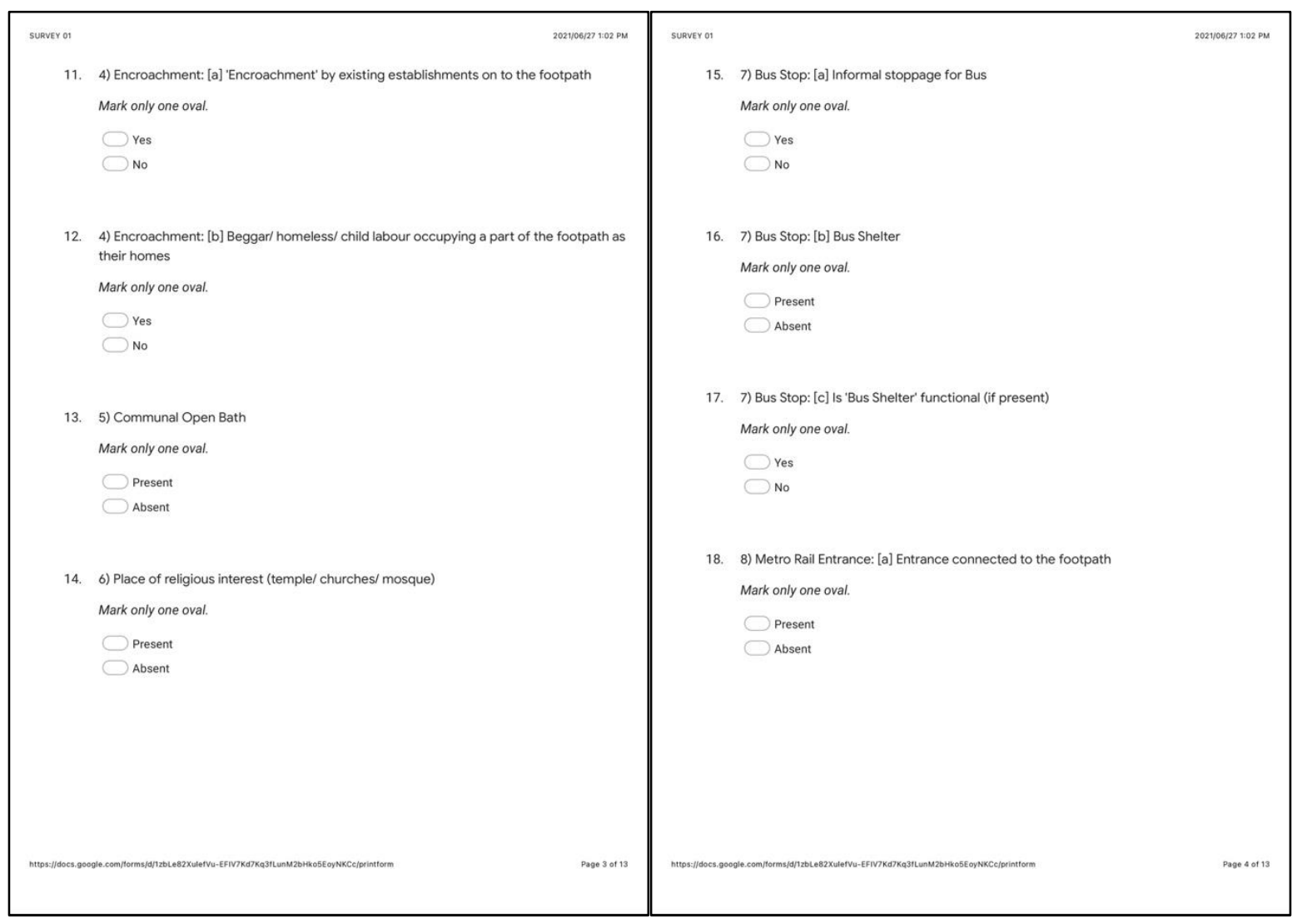




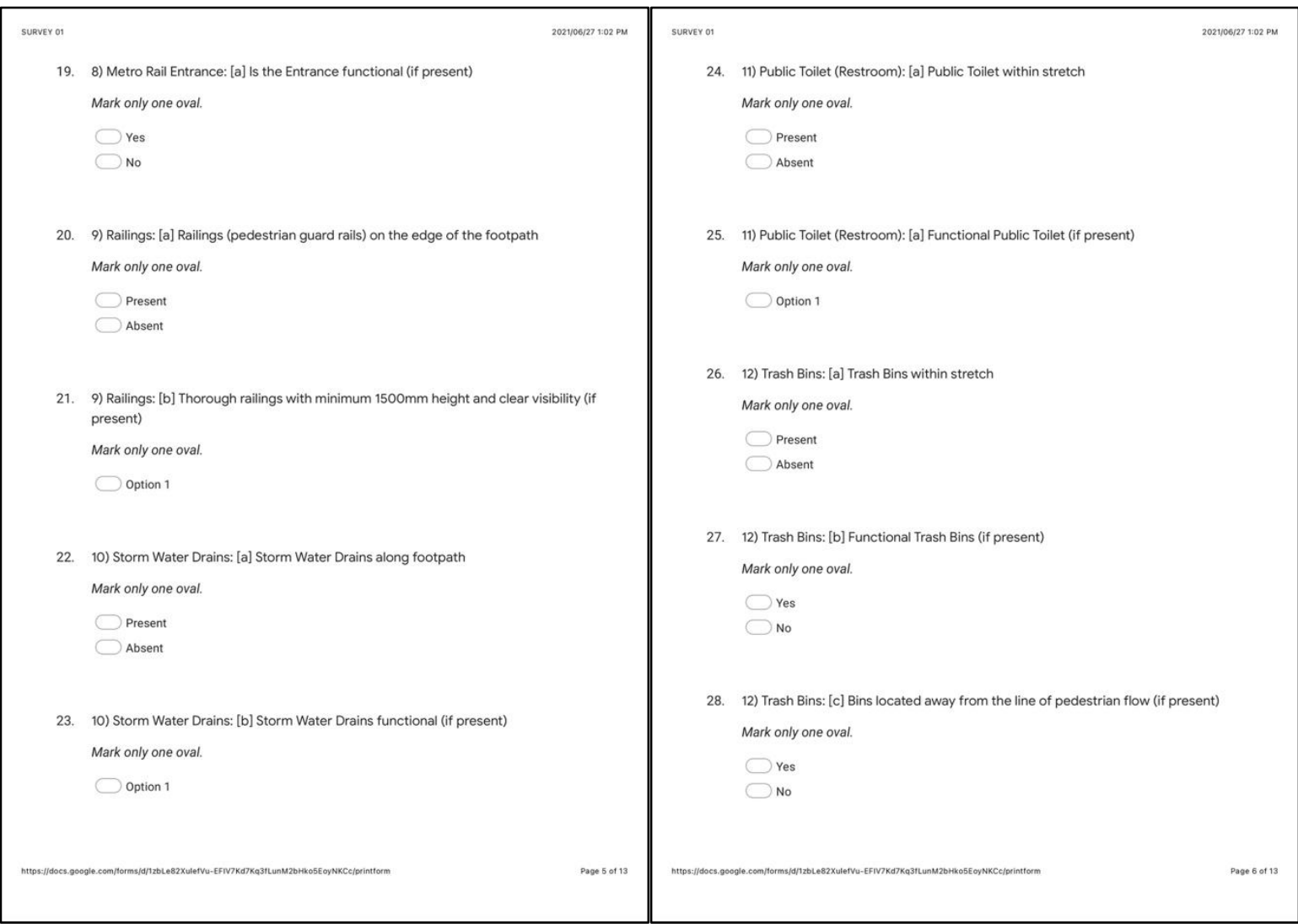

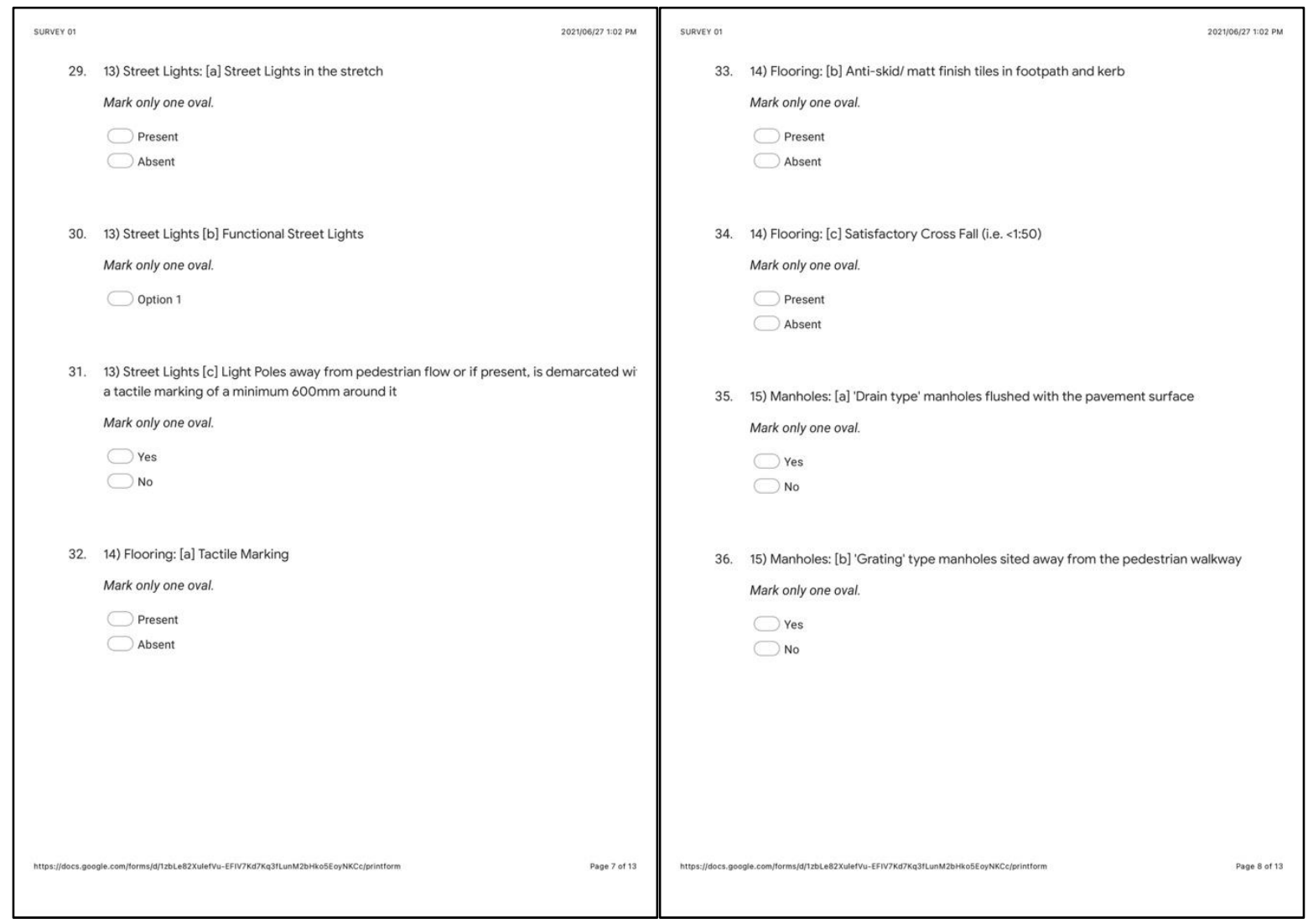




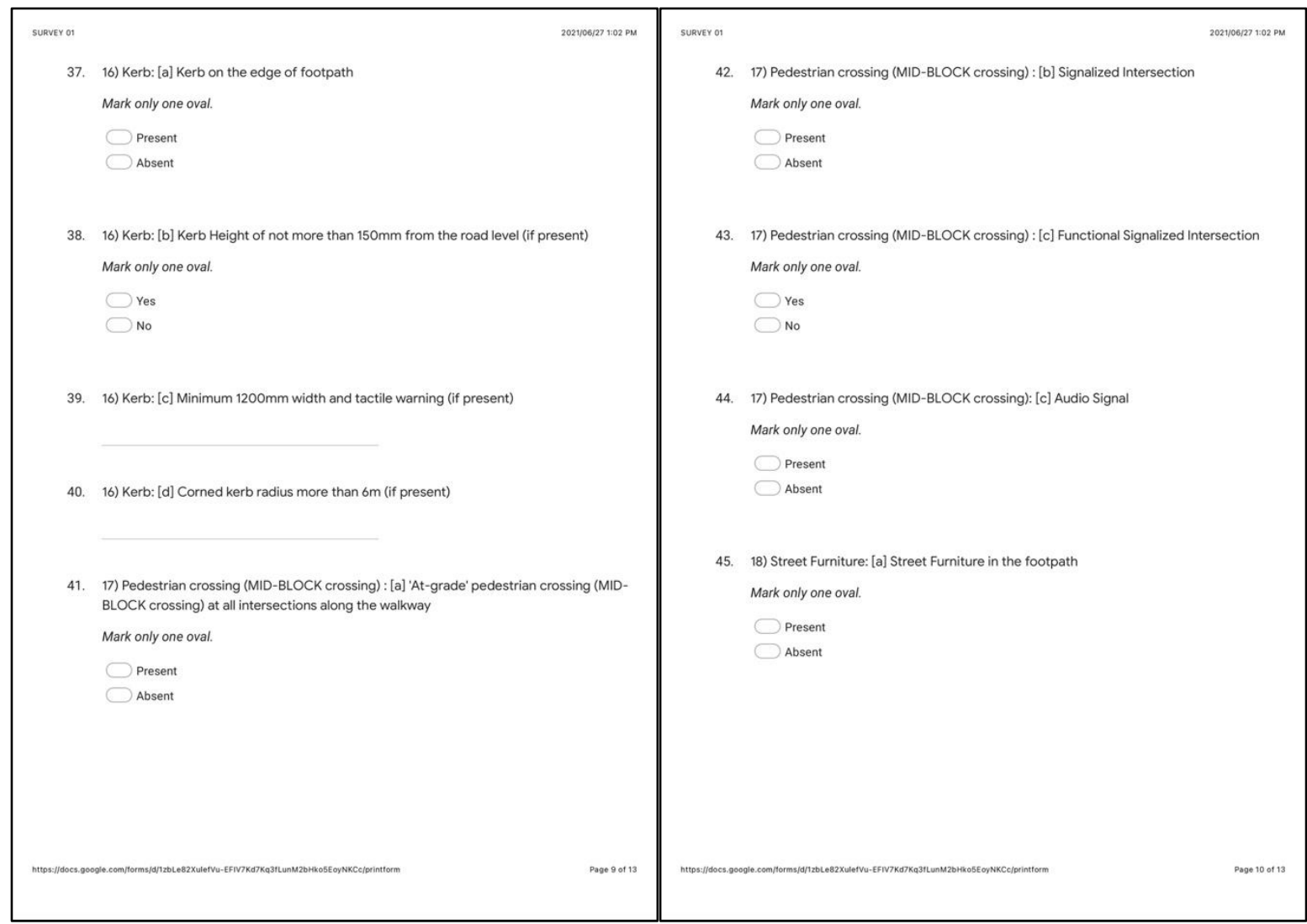

\begin{tabular}{|c|c|c|c|c|}
\hline suaver or & 2021/08/27 1:02 PM & suaver or & & $2021 / 06 / 27$ : $102 \mathrm{PM}$ \\
\hline 46. & $\begin{array}{l}\text { 18) Street Furniture: [b] Street furniture having a knee clearance of a minimum of } 700 \mathrm{~mm} \\
\text { and wheelchair space of } 1000 \mathrm{~mm} \\
\text { Mark only one oval. } \\
\text { Yes } \\
\text { No }\end{array}$ & 50. & $\begin{array}{l}\text { 19) Additional Inclusive features: [d] Public Drinking Water Facility } \\
\text { Mark only one oval. } \\
\text { Present } \\
\text { Absent }\end{array}$ & \\
\hline 47. & $\begin{array}{l}\text { 19) Additional Inclusive features: [a] Signage } \\
\text { Mark only one oval. } \\
\text { Present } \\
\text { Absent }\end{array}$ & 51. & $\begin{array}{l}\text { 20) Safety and Security: [a] Fire Hydrant } \\
\text { Mark only one oval. } \\
\text { Present } \\
\text { Absent }\end{array}$ & \\
\hline 48. & $\begin{array}{l}\text { 19) Additional Inclusive features: [b] Bicycle Track } \\
\text { Mark only one oval. } \\
\text { Present } \\
\text { Absent }\end{array}$ & 52. & $\begin{array}{l}\text { 20) Safety and Security: [b] Security Camera } \\
\text { Mark only one oval. } \\
\square \text { Present } \\
\text { Absent }\end{array}$ & \\
\hline 49. & $\begin{array}{l}\text { 19) Additional Inclusive features: [c] Public Drinking Water Facility } \\
\text { Mark only one oval. } \\
\text { Present }_{\text {Absent }}\end{array}$ & & $\begin{array}{l}\text { This content is nether created nor endorsed by Google. } \\
\text { Google Forms }\end{array}$ & \\
\hline httess//doces,900 & 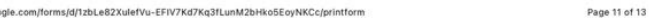 & nttps://doces.90 & 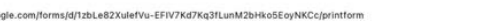 & Page 12 of 13 \\
\hline
\end{tabular}


Individual score for each of the thirty-two stretches in response to the eighteen criteria

\section{S.No.} Surveyed Stretches

Achieved Score (in \%)

\begin{tabular}{|c|c|c|}
\hline 1 & Nirmal Chandra Dey Street & -37.5 \\
\hline 2 & Bowbazar Crossing to New Bowbazar Lane & -35.0 \\
\hline 3 & New Bowbazar lane & -12.5 \\
\hline 4 & New Bowbazar Lane to Kenderdine Lane & -32.5 \\
\hline 5 & Kenderdine Lane & -20.0 \\
\hline 6 & Kenderdine Lane to Central Avenue & -50.0 \\
\hline 7 & Central Avenue (GATE 4_Yogayog Bhawan) & -42.5 \\
\hline 8 & Central Metro(GATE 1_Indian Airlines) & -32.5 \\
\hline 9 & Central Avenue to Bow Street & -35.0 \\
\hline 10 & Bow Street & -12.5 \\
\hline 11 & Bow Street to Metcalfe Street & -25.0 \\
\hline 12 & Metcalfe Street & -22.5 \\
\hline 13 & Metcalfe Street to Bentinck Street & -27.5 \\
\hline 14 & Bentinck Street & -37.5 \\
\hline 15 & Rabindra Sarani Rd. & -30.0 \\
\hline 16 & Rabindra Sarani Rd. to Chatawalla Gully & -25.0 \\
\hline 17 & Chatawalla Gully & -10.0 \\
\hline 18 & Chatawalla Gully to Phears Bye Lane & -22.5 \\
\hline 19 & Phears Bye Lane & -30.0 \\
\hline 20 & Phears Bye Lane to Phears Lane & -35.0 \\
\hline 21 & Phears Lane & -17.5 \\
\hline 22 & Phears Lane to Giri Babu lane & -27.5 \\
\hline 23 & Giri Babu lane & -30.0 \\
\hline 24 & Giri Babu lane to Central Avenue & -42.5 \\
\hline 25 & Central Metro (GATE 2_Lalbazar) & -30.0 \\
\hline 26 & Central Avenue (GATE 3_RITES) & -25.0 \\
\hline 27 & Central Avenue to Gangadhar Babu Lane & -62.5 \\
\hline 28 & Gangadhar Babu lane & -30.0 \\
\hline 29 & Gangadhar Babu Lane to Bibi Rozio Lane & -57.5 \\
\hline 30 & Bibi Rozio Lane & -45.0 \\
\hline 31 & Bibi Rozio Lane to Bowbazar Crossing & -30.0 \\
\hline 32 & College Street & -57.5 \\
\hline
\end{tabular}

Graph showing the scores of 32 sub-stretches

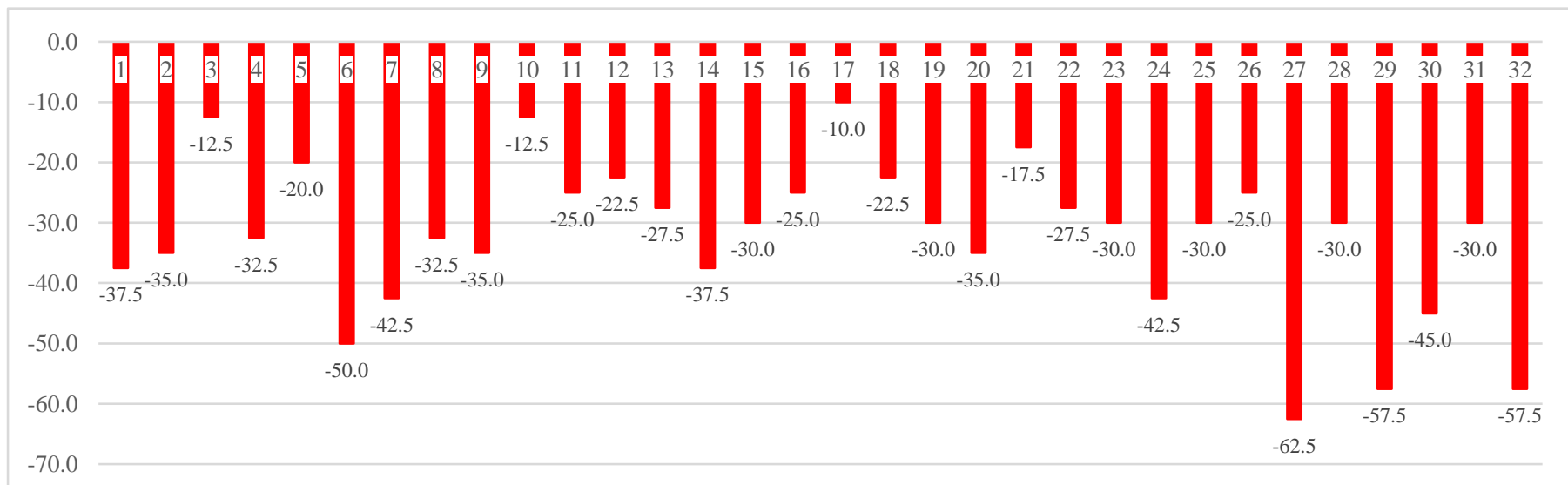

\section{References}


[1] K. Funahashi, "Transactional Perspective, Design, and "Architectural Planning Research" in Japan," in Handbook of Japan-United States Environment-Behavior Research [https://doi.org/10.1007/978-1-4899-0286-3_24], S. Wapner, J. Demick, T. Yamamoto and T. Takahashi, Eds., Boston, MA, Springer, 1997, pp. 355-364.

[2] Y. Matsuda, "A brief history of architectural planning research in Japan," Japan Architectural Review [https://doi.org/10.1002/2475-8876.12160], vol. 3, no. 3, pp. 269-270, 2020.

[3] R. Mace, "Universal Design: barrier free environmment for everyone," Designers West, vol. 33, no. 1, pp. 147-152, 1985.

[4] N. Rea, "Italy hits architect Santiago Calatrava with €78,000 in fines," 2019. [Online]. Available: https://www.artcritique.com/en/2019/08/italy-fines-santiago-calatrava-e78000-because-of-venice-bridge/. [Accessed 14 June 2021].

[5] S. Goldsmith, Universal Design: A Manual of Practical Guidance for Architects, Oxford: Architectural Press, 2000, pp. 1-11.

[6] L. L. Naussbaumer, Inclusive Design - A Universal Need, 2nd Edition ed., New York: Fairchild Books (Bloomsbury Fairchild Books), 2019, pp. 1-51.

[7] C. A. Thoma, C. C. Bartholomew, L. A. Scott, B. A. Bader, S. E. Perez and M. Bryant, "Universal Design for Transition and Community Living," in Universal Design for Transition, C. A. Thoma, C. C. Bartholomew and L. A. Scott, Eds., London, Paul H. Brookes Publishing Co., 2009, pp. 139-160.

[8] G. L. Albrecht, Ed., Encyclopedia of Disability [http://dx.doi.org/10.4135/9781412950510], Illinois: SAGE Publications, Inc., 2006.

[9] I. Marini, "The History of Treatment Toward People with Disabilities," in Psychosocial Aspects of Disability, I. Marini, N. M. Graf and M. J. Millington, Eds., New York, Springer Publishing Company, 2018, pp. 3-32.

[10] C. H. McNabb, "Medieval Disability Sourcebook: Western Europe," in Medieval Disability Sourcebook: Western Europe, C. H. McNabb, Ed., Punctum Books, 2020, p. https://doi.org/10.2307/j.ctv11hptcd.

[11] A. P. Hobgood and D. H. Wood, Recovering Disability in Early Modern England, 1st Edition ed., Columbus: The OhiO STaTe UniverSiTy PreSS, 2013.

[12] D. M. Turner and D. Blackie, Disability in the Industrial Revolution Physical impairment in British coalmining, 1780-1880, 1st Edition ed., Manchester: Manchester University Press, 2018.

[13] S. Gupta, L. P. d. Witte and A. Meershoek, "Dimensions of invisibility: insights into the daily realities of persons with disabilities living in rural communities in India," Disability E Society, pp. 1-23, 2020.

[14] N. Kumari, "Karmic Philosophy and the Model of Disability in Ancient India," International Journal of Arts, Science and Humanities [https://doi.org/10.34293/sijash.v7i1.531], vol. 7, no. 1, pp. 39-43, 2019.

[15] R. Dawn, "The Portrayal of Disability in Indian Culture An Attempt at Categorization," Kalyani, 2015.

[16] G Narayana Raju, THE CONSTITUTION OF INDIA[As on 31st July, 2018], New Delhi: LEGISLATIVE DEPARTMENT, MINISTRY OF LAW AND JUSTICE, GOVERNMENT OF INDIA, 2018.

[17] G. D. Mahapatra, "Neighborhood Planning: Approach in Improving Livability and Quality of the Life in the Cities," in Understanding Built Environment. Springer Transactions in Civil and Environmental Engineering [https://doi.org/10.1007/978-981-10-2138-1_5], F. Seta, A. Biswas and J. Sen, Eds., Singapore, Springer, 2017, pp. 4753.

[18] G. D. Mahapatra, S. Mori and R. Nomura, "Universal Mobility in Old Core Cities of India: People's Perception," Sustainability (DOI: https://doi.org/10.3390/su13084391), vol. 13, no. 8, pp. 1-36, 2021. 
[19] World Health Organization, "Global Age-friendly Cities: A Guide," WHO Press, Geneva, 2007.

[20] Department of Empowerment of Persons with Disabilities, Ministry of Social Justice \& Empowerment, "Accessible India Campaign; Accessible India - Empowered India," Government of India, New Delhi, 2015.

[21] NIUA, "Project Details: BASIIC," 18 2019. [Online]. Available: https://www.niua.org/projectdetails?pid=26. [Accessed 612021 ].

[22] D. Dutta, "Portuguese in Bengal: A History Beyond Slave Trade," 09 August 2019. [Online]. Available: https://www.sahapedia.org/portuguese-bengal-history-beyond-slave-trade. [Accessed 06 May 2021].

[23] K. Sarda, "Kolkata's Armenian Legacy," 20 June 2017. [Online]. Available: https://www.livehistoryindia.com/story/amazing-india/kolkatas-armenian-legacy/. [Accessed 06 May 2021].

[24] O. Lahiri, "OVERVIEW OF CHINSURAH," 01 November' $2015 . \quad$ [Online]. Available: http://www.dutchinchinsurah.in/overview.php. [Accessed 06 May 2021].

[25] V. Ganesan, "A French colony that fought the British," 02 July 2012. [Online]. Available: https://www.thehindu.com/books/a-french-colony-that-fought-the-british/article3595158.ece. [Accessed 06 May 2021].

[26] G. D. Mahapatra, "The Imperial Goldmine-Kolkata," Urban Update (https://issuu.com/urbanupdatemag/docs/uu_20november_202017), vol. 4, no. 7, pp. 36-37, 20 Novenmber 2017.

[27] C. Jain, "The Change of Capital in 1911," The Proceedings of the Indian History Congress, vol. 34, no. 2, pp. 45-47, 1973.

[28] Q. Alam, "Historical Overview of Torture and Inhuman Punishments in Indian Sub-continent," Journal of the Punjab University Historical Society, vol. 31, no. 2, pp. 127-136, 2018.

[29] S. Chattopadhyay, Representing Calcutta- Modernity, Nationalism, and the Colonial Uncanny [ISBN 0-415-392160], 1st Edition ed., New York: Routledge, 2006.

[30] M. Islam, "Big National Parties in West Bengal- An exceptional outcast," in Rise of Saffron Power- Reflections on Indian Politics [https://doi.org/10.4324/9780429506321], M. Rehman, Ed., London, Routledge India, 2018, pp. 279-296.

[31] R. Das and Z. Mahmood, "Contradictions, Negotiations and Reform: The Story of Left Policy Transition in West Bengal," Journal of South Asian Development [DOI: 10.1177/0972150915591392], vol. 10, no. 2, pp. 199-229, 2015.

[32] S. Nath, "'Cultural misrecognition' and the sustenance of trinamool congress in West Bengal," Economic and Political Weekly [https://www.epw.in/system/files/pdf/2018_53/28/SA_LIII_28_140718_Suman_Nath.pdf], vol. 53, no. 28, pp.92$99,2018$.

[33] N. Wahi, "Land conflict rampant in India because Constitution has made sparse reference to it," 28 February 2020. [Online]. Available: https://heprint.in/opinion/land-conflict-rampant-in-india-because-constitution-has-madesparse-reference-to-it/372597/. [Accessed 28 June 2021].

[34] G. D. Mahapatra and K. Puntambekar, Reinterpreting Urban Fabric in Cities with Living Heritage: The Case of Central Kolkata [ISBN 978-9383419883], 1st Edition ed., T. Mitra, Ed., Delhi: COPAL Publishing Group, 2020.

[35] G. D. Mahapatra and N. R. Mandal, Re-inventing Urban Spaces by accessing accessibility in old city core- A case of Kolkata, Chisinau: Lap Lambert Academic Publishing, 2019, pp. 11-17.

[36] K. Gregg and P. Hess, "Complete streets at the municipal level: A review of American municipal Complete Street Policy," International Journal of Sustainable Transportation (DOI: https://doi.org/10.1080/15568318.2018.1476995), vol. 13, no. 6, pp. 407-418, 2019. 
[37] C. M. Werner, B. B. Brown, T. Stump, C. P. Tribby, W. Jensen, H. J. Miller, A. Strebel and A. Messina, "Street use and design: daily rhythms on four streets that differ in rated walkability," Journal of Urban Design (DOI: https://doi.org/10.1080/13574809.2018.1448706), vol. 23, no. 4, pp. 603-619, 2018.

[38] Å. Svensson, Ed., Arterial Streets for People, Lund: European Commission Fifth Framework Programme, 2004, pp. 18-25, 53.

[39] A. Martire, "Walking the Streets: No More Motorways for Belfast," Spaces and Flows: An International Journal of Urban and ExtraUrban Studies (DOI: https://doi.org/10.18848/2154-8676/CGP/v08i03/35-61), vol. 8, no. 3, pp. 35-61, 2017.

[40] B. Hillier, A. Penn, J. Hanson, T. Grajewski and J. Xu, "Natural Movement: Or, Configuration and Attraction in Urban Pedestrian Movement," Environment and Planning B: Planning and Design (DOI: https://doi.org/10.1068/b200029), vol. 20, no. 1, pp. 29-66, 1993.

[41] S. S. S. Mahdzar, "STREETS FOR PEOPLE:Sustaining accessible and sociable streets in Pasir Gudang city centre," in Proceedings of the Ninth International Space Syntax Symposium, Seoul, 2013.

[42] K. Fang, X. Wang, W. Zhang, Z. Zhang, Y. Xie, L. Chen, G. Zhu and N. Furuya, "Characteristics of space network system formed by the constituent elements in urban streets: Tianzifang in Shanghai as a case study," Journal of Asian Architecture and Building Engineering (DOI: 10.1080/13467581.2020.1803078), 2020.

[43] M. Southworth, "Listening to the city," Journal of Urban Design (DOI: https://doi.org/10.1080/13574809.2020.1809884), vol. 25 , no. 5, pp. 556-560, 2020.

[44] K. T.Geurs and V. W. Bert, "Accessibility evaluation of land-use and transport strategies: review and research directions," Journal of Transport Geography (https://doi.org/10.1016/j.jtrangeo.2003.10.005), vol. 12, no. 2, pp. 127-140, 2004.

[45] R. Kitchin and R. Law, "The Socio-spatial Construction of (In)accessible Public Toilets," Urban Studies, vol. 38, no. 2, p. 287-298, 2001.

[46] P. J. Troped, E. K. Cromley, M. S. Fragala, S. J. Melly, H. H. Hasbrouk, S. L. Gortmaker and R. C. Brownson, "Development and Reliability and Validity Testing of an Audit Tool for Trail/Path Characteristics: The Path Environment Audit Tool (PEAT)," Journal of Physical Activity and Health, vol. 3, no. 1, pp. 158-175, 2006.

[47] S. Tabatabaee, M. Aghaabbasi, A. Mahdiyar, R. Zainol and S. Ismail, "Measurement Quality Appraisal Instrument for Evaluation of Walkability Assessment Tools Based on Walking Needs," Sustainability [DOI: https://doi.org/ 10.3390/su132011342], vol. 13, no. 11342, pp. 1-22, 2021.

[48] Z. Qi, S. Lim and T. H. Rashidi, "Assessment of transport equity to Central Business District (CBD) in Sydney, Australia," Transportation Letters: The International Journal of Transportation Research, vol. 12, no. 4, pp. 246-256, 2020.

[49] M. A. Saif, M. M. Zefreh and A. Torok, "Public Transport Accessibility: A Literature Review," Periodica Polytechnica Transportation Engineering (DOI: https://doi.org/10.3311/PPtr.12072), pp. 1-8, 2018.

[50] A. Mondschein, E. Blumenberg and B. Taylor, "Accessibility and Cognition: The Effect of Transport Mode on Spatial Knowledge," Urban Studies (DOI: https://doi.org/10.1177/0042098009351186), vol. 47, no. 4, p. 845-866, 2010.

[51] Shaffrey Associates Architects and Fionnuala Rogerson Architects, "Access: Improving Accessibility of Historic Buildings and Places," National Disability Authority of Ireland, Government of Ireland, Dublin, 2011.

[52] D. Mahadevia, T. Munshi and R. Joshi, "A Methodology for Local Accessibility Planning in Indian Cities," Centre for Urban Equity, CEPT University (DOI: 10.13140/RG.2.1.1742.8645), Ahmedabad, 2014. 
[53] P. A. Akbar, V. Couture, G. Duranton, E. Ghani and A. Storeygard, "Mobility and Congestion in Urban India," World Bank Group (Macroeconomics, Trade and Investment Global Practice), Berkeley, 2018.

[54] M. Brussel, M. Zuidgeest, K. Pfeffer and M. v. Maarseveen, "Access or Accessibility? A Critique of the Urban Transport SDG Indicator," International Journal of Geo-Information (DOI: https://doi.org/10.3390/ijgi8020067), pp. 1$23,2019$.

[55] T. Litman, "Accessibility for Transportation Planning," Victoria Transport Policy Institute, Victoria, 2016.

[56] M. Prajapati, M. Advani and P. Parida, "Identifying the most suitable road crossing infrastructure based on estimated delay to pedestrians and vehicle users," Transportation Letters: The International Journal of Transportation Research (DOI: https://doi.org/10.1080/19427867.2016.1237821), vol. 10, no. 2, pp. 113-127, 2018.

[57] G. Evans, "Accessibility, Urban Design and the Whole Journey Environment," Built Environment, vol. 35, no. 3, pp. 366-385, 2009.

[58] Taylored Accessibility Solutions Limited, "MOBILITY SPACES AND STREET ACCESSIBILITY AUDIT REPORT," CCS Disability Action, Te Awamutu, 2013.

[59] Matrix Partnership Ltd, Nortoft Partnerships Ltd, Alan Baxter Associates, Lambert Smith Hampton, "Town Centre Area Action Plan - Baseline Study," Borough Council of Wellingborough, Wellingborough, 2003.

[60] C. O'Fallon, "Auditing public transport accessibility in New Zealand," NZ Transport Agency, Wellington, 2010.

[61] A. Sdoukopoulos, E. Verani, A. Nikolaidou, A. Tsakalidis, G. Nikolaos, M. Pitsiava-Latinopoulou, F. Mikiki, E. Mademli and C. Pallas, "Development and implementation of walkability audits in Greek medium-sized cities: the case of the Serres' city centre," in 3rd Conference on Sustainable Urban Mobility, 3rd CSUM 2016, 26 - 27 May 2016 (DOI: https://doi.org/10.1016/j.trpro.2017.05.102), Volos, 2016.

[62] Centers for Disease Control and Prevention, "Walkability Audit Tool," U.S Department of Health and Human Services, Atlanta, 2005.

[63] M. F. Story and J. L. Mueller, "UNIVERSAL DESIGN PERFORMANCE MEASURES FOR PRODUCTS TO SUPPORT THE PRACTICE OF UNIVERSAL DESIGN," in PROCEEDINGS of the HUMAN FACTORS AND ERGONOMICS SOCIETY 48th ANNUAL MEETING (DOI:10.1177/154193120404800808), New Orleans, 2004.

[64] G. Scott, "STREETSCAPE AUDIT: Geelong Hospital Precinct," Council of City of Greater Geelong, Geelong, 2018.

[65] K. M. Wieters, "Advantages of Online Methods in Planning Research: Capturing Walking Habits in Different Built Environments," SAGE Open (DOI: https://doi.org/10.1177/2158244016658082), pp. 1-11, 2016.

[66] E. I. Mosca and S. Capolongo, "Towards a Universal Design Evaluation for Assessing the Performance of the Built Environment," Studies in Health Technology and Informatics, Volume 256: Transforming our World Through Design, Diversity and Education (DOI: 10.3233/978-1-61499-923-2-771), vol. 256, pp. 771-779, 2018.

[67] M. Taleai and E. T. Amiri, "Spatial multi-criteria and multi-scale evaluation of walkability potential at street segmnet level: A case study of Tehran," Sustainable Cities and Society (DOI: https://doi.org/10.1016/j.scs.2017.02.011), vol. 31, pp. 37-50, 2017.

[68] Roads and Traffic Authority NSW, "How to prepare a Pedestrian Access and Mobility Plan - An easy three stage guide," New South Wales Government, Sydney, 2002.

[69] F. Zhang, L. Wu, D. Zhu and Y. Liu, "Social Sensing from street-level imagery: A case study in learning spatiotemporal urban mobility patterns," ISPRS Journal of Photogrammetry and Remote Sensing (DOI: https://doi.org/10.1016/j.isprsjprs.2019.04.017), vol. 153, pp. 48-58, 2019. 
[70] M. Dhingra and S. Chattopadhyay, "Advancing smartness of traditional settlements - case analysis of Indian and Arab old cities," International Journal of Sustainable Built Environment (DOI: https://doi.org/10.1016/j.ijsbe.2016.08.004), vol. 5, pp. 549-563, 2016.

[71] NCPEDP, "Making Disable Friendly Smart Cities," National Centre for Promotion of Employment for Disabled People, Delhi, 2016.

[72] FICCI \& NCPEDP, "Structural Framework for Accessible Urban Infrastructure in Smart Cities," National Centre for Promotion of Employment for Disabled People and Federation of Indian Chamber of Commerce \& Industry, Delhi, 2016.

[73] P. Lansley, "Towards an inclusive society," Building Research $\mathcal{E}$ Information (DOI: https://doi.org/10.1080/0961321021000036880), vol. 31, no. 1, pp. 70-72, 2010.

[74] S. Gupta, "White paper on Achieving Infrastrctural Accessibility in India \& 5 year Action Plan," Ministry of Social Justice and Empowerment, Government of India, New Delhi, 2018.

[75] Square Unit Private Limited, "Report on Accessibility Audit in Kathmandu, Nepal," National Federation of the Disabled - Nepal (NFDN), Kathmandu, 2018.

[76] P. S. Raikhola and Y. Kuroki, "Aging and Elderly Care Practice in Japan: Main Issues, Policy and Program Perspective; What Lessons can be Learned from Japanese Experiences?," Dhaulagiri Journal of Sociology and Anthropology, vol. 3, pp. 41-82, 2010.

[77] Indian Road Congress, "Guidelines for Pedestrian Facilities [IRC: 103-2012]," Aravali printers and Publishers, New Delhi, 2012.

[78] S. Mori, T. Oku and M. Hasegawa, "Characteristics of Action in Strolling Behavior: A Basic Study on Act-finding in Urban Space," in Proceedings of the 5th International Symposium for Environment-Behavior Studies, Shanghai, 2002.

[79] J. Espina, S. Mori and R. Nomura, "An Analysis of Environment Behavior Relationships towards the Design of a Local Mixed-used Street: Based on Behavior Settings of Belgium Street in Cebu City, Philippines," Sustainability [https://doi.org/10.3390/su10093230], vol. 10, no. 9, pp. 1-20, 2018.

[80] D. T. Do, S. Mori and R. Nomura, "An Analysis of Relationship between the Environment and User's Behavior on Unimproved Streets: A Case Study of Da Nang City, Vietnam," Sustainability [https://doi.org/10.3390/su11010083], vol. 11, no. 1, pp. 1-19, 2019.

[81] D. T. Do and S. Mori, "Developed vs. undeveloped streets in Da Nang, Vietnam: which are more usable, and for whom?," Journal of Urbanism: International Research on Placemaking and Urban Sustainability [DOI: 10.1080/17549175.2021.1893797], pp. 1-27, 2021.

[82] M. F. Story, J. L. Mueller and R. L. Mace, The Universal Design File: Designing for People of All Ages and Abilities, Revised ed., Raleigh, North Carolina: Center For Universal Design, NC State University, 1998, pp. 5-79. 